Review Article

\title{
Agricultural Microbiology Research Progress in India in the New Millennium
}

\author{
DLN RAO*,1, TK ADHYA ${ }^{2}$ and AK SAXENA ${ }^{3}$ \\ ${ }^{1}$ ICAR-Indian Institute of Soil Science, Bhopal 462 038, Madhya Pradesh, India \\ ${ }^{2}$ KITS University, Bhubaneswar 751 024, Odisha, India \\ ${ }^{3}$ ICAR-National Bureau of Agriculturally Important Micro-organisms, Mau 275 103, U.P., India
}

(Received on 03 April 2019; Accepted on 25 October 2019)

\begin{abstract}
The research efforts in microbiology over last two decades have focussed on assessing the microbial diversity in various soil types and cropping systems in all agro-eco-regions, including extreme environments resulting in creation of a vast repository of microorganisms, free living and endophytes. A marked departure from the past is their identification by both conventional and molecular methods, resulting in discovery of many novel species. The effects of various soil and agronomic management practices were assessed on soil microbial diversity and soil health by both classical and metagenomic approach. The beneficial effects of organic and integrated farming, and adverse effects of chemical intensification have been assessed, leading to the identification of actinobacteria as important players in maintaining soil health. A major impact has been the firm attention received from policy makers on the urgent need to conserve soil biodiversity and improve soil health. Identification of rapid methods of soil biological health assessment, improved rhizobial inoculants, microbial technology for rapid in situ and ex situ residue and waste breakdown, and mitigating climate change effects are the current priorities. Future priorities include assessment of the structure and function of the vast reservoir of unculturable microbes; deleterious microorganisms, assessment of soil-plant-microbe continuum and plant immunity modulation by microbes; rhizosphere engineering, role of archaea in maintaining soil health, microbial methods to improve soil organic matter formation; assessment and quantification of ecosystem services rendered by agriculturally important microorganisms; and improved microbial technology for biofertilizers and delivery systems. The tremendous advances in agricultural microbiology in last two decades in India are a cause for optimism that solutions will be forged for the above challenges using both classical and modern approaches, thereby ushering in the process more sustainable agricultural systems.
\end{abstract}

Keywords: Biological Nitrogen Fixation; Biofertilizers; Climate Change; Endophytes; Microbial Diversity; Plant Growth Promoting Bacteria; Soil Bioremediation; Soil Health

\section{Introduction}

The major research concerns in Agricultural Microbiology in India during the last decade have all revolved around ecological principles and practices that ensure sustainable production systems that are economically viable and environmentally safe. The adverse effects of agricultural intensification on soil biodiversity in a background of the already low soil organic matter levels, diminished organic recycling (green manuring, composts), imbalanced chemical fertilization, indiscriminate usage of agro-chemicals, land disposal of industrial effluents etc., have firmly

*Author for Correspondence: E-mail: desiraju.rao@gmail.com brought the attention of the researchers and policy makers to the urgent need to conserve soil biodiversity and improve soil biology (Rao et al., 2015). Assessment of soil microbial diversity in different agroecosystems; identification of soil biological health indicators; improvement of legume biological nitrogen fixation through efficient and competitive rhizobial inoculants; improving plant health by inoculation with plant growth promoting rhizobacteria biofertilizers; identification of microbial cultures for rapid degradation of agricultural wastes; role of microorganisms in mitigation of green house gases are some of the major thrust areas that received (and 
continue to receive) the attention of agricultural microbiologists. A major shift in research approachlinking the classical approach to molecular approach using genomic tools was decisively made in all the laboratory investigations as well in some field studies. Another major development was the close linkages developed by microbiologists with soil chemists and physicists, agronomists, molecular biologists, bioinformaticians, climate change researchers and social scientists. A system approach replaced the piece-meal approach in field research. The outcome of these research efforts led to answers to some pressing questions like: How are some of our agricultural management practices impacting soil biodiversity, ecosystem processes and in turn soil health? How can application of microbial biotechnology help in improving soil biology, saving chemical fertilizers, improve biological nitrogen fixation, improve nutrient use efficiency and sustainable agricultural intensification? Some of those major developments are highlighted in this review.

\section{Soil Microbial Diversity}

\section{Bacteria}

India is one among 12 mega-biodiversity countries and 25 hotspots of the richest and highly endangered eco-regions of the world. Efforts were made in the last ten years to survey and enlist the biodiversity of certain groups of bacteria, fungi and cyanobacteria. The Indian Council of Agricultural Research (ICAR) initiated a program in year 2002 under the aegis of the All India Coordinated Research Project on Biological Nitrogen Fixation to survey the various districts of Madhya Pradesh for nodulation of soybean and characterize the native population of its rhizobia. Results showed that these soils largely harbored the slow growing rhizobia (Saxena 2006; Rawat et al., 2008). Indigenous soybean rhizobia in Vertisols of Central India and other soils were assessed for cross nodulation, bacteriocin production and competitiveness (Ansari and Rao, 2013; 2014; Ansari et al., 2014). Attempts were also made to study the diversity of rhizobia specific to chickpea (Rai et al., 2012; Yadav et al., 2013; Suneja et al., 2016); pea (Wadhwa et al., 2011) and Vicia faba (Gera et al., 2013). Besides Rhizobium, diversity of Azotobacter and other free living diazotrophs in the rhizosphere of foot yam (Anjanadevi et al., 2013) and red kidney beans (Suyal et al., 2015); in salt affected soils of Haryana (Kayasth et al., 2014); in the semi-arid Alfisol receiving long-term organic and inorganic nutrient amendments (Cinnadurai et al., 2013) and in Indian agricultural lands (Anima and Singh, 2011) have also been reported.

Western Ghats are the hot spots of diversity and have been explored by different workers for various groups of microorganisms. Diversity of endorhizospheric diazotrophs and Beijerinckia (Alagawadi et al., $2014 \mathrm{a}, \mathrm{b}$ ); Bacillus thuringiensis (Ramalakshmi and Udayasuriyan, 2010); methylotrophic bacteria (Rahul Sri Balaji, 2013) and fluorescent pseudomonads (Indi and Alagawadi, 2012) were some of the reports from Western Ghats and were reviewed in detail by Naampoothiri et al. (2013). Few significant developments, particularly in India, to understand the relationship of soils and plants with the diversity of associated bacteria were reviewed by Tilak et al. (2005). It also traces contributions of Indian scientists in isolating and defining the roles of plant growth promoting bacteria to evolve strategies for their better exploitation. The diversity of plant growth promoting bacteria was assessed in the rhizosphere soil of tropical rice plant in Odisha (Bal et al., 2012), wheat in northern hills and Central zone of India (Verma et al., 2014, 2015); Terai-Dooars regions of North Bengal (Dey et al., 2013); North Western Indian Himalayas (Yadav et al., 2016a) and diverse agroecosystems of India for Sorghum bicolor (Praveen Kumar et al., 2012). Asokan et al. (2013) reported the first isolation and characterization of native Bacillus thuringiensis isolates in soils of Great Nicobar Islands. Some of these isolates displayed toxic potential and could be adopted for future applications to control some agriculturally important insect pests in the area.

In another study epiphytic pink pigmented methylotrophic bacteria isolated from the phyllosphere of different crop plants were reported to enhance germination and seedling growth of wheat (Triticum aestivum) by producing phytohormones (Meena et al., 2011). Indigenous formulations based on cow dung fermentation (biodynamic preparations: Panchagavya, BD500 and CPP) were analyzed by Radha and Rao (2014) who reported high counts of lactobacilli $\left(10^{9}\right)$ and yeasts $\left(10^{4} \mathrm{ml}^{-1}\right)$. Bacillus safensis, Bacillus cereus, Bacillus subtilis, Lysinibacillus 
xylanilyticus and Bacillus licheniformis were isolated and found to have PGPR attributes and improved the growth of maize. This is the first report of L. xylanilyticus and B. licheniformis in biodynamic preparations.

The microbial diversity all over the world in several specialized habitats of deserts, viz., patina (desert varnish), cryptobiotic crusts, saline playas and rhizosheath was reviewed (Bhatnagar and Bhatnagar 2005). There are several reports by different research groups on the diversity of microorganisms in different extreme environments of the country which may harbor novel microflora. The extreme environments surveyed includes Sunderbans and Bhitarkanika Mangroves, thermal springs at Manikaran (Singh et al., 2010), Soldhar, Rajgiri, Vashist, Balarampur and Bakreshwar thermal springs, Chilka lake, Odisha, Pulicat brackish water lake, Sambhar Salt Lake, Lonar Lake; Rann of Kutch, Gujarat, Leh and Drass cold desert, Pindari, Kafni and Roopkund glacier, Himalayan mountain ranges; Kovalam district of Kerala, Jaisalmer, Rajasthan; Andaman \& Nicobar island; estuarine sediments on Central west coast (Singh et al., 2010); deep-sea sediments of the Central Indian Basin (Singh et al., 2010); sediments of oxygen minimum zone in the Arabian Sea and Calcutta wet lands (Singh et al., 2012; Yadav et al., 2011; 2015a,b,c; 2016; Sahay et al., 2011; 2012a,b; Srinivasan et al., 2011; Thomas et al., 2012; Singh et al., 2013; Kumar et al., 2013b; 2014; Sharma et al., 2015; Sharma et al., 2015; Shivaji et al., 2011; Srinivas et al., 2011; Gupta et al., 2015; Ghosh et al., 2010; Pradhan et al., 2010). Bacterial diversity analyses of soil in the vicinity of Pindari glacier (India) showed the presence of diverse groups of organisms belonging to the genera Arthrobacter, Bacillus, Sporosarcina, Rhodococcus, Lysinibacillus, Pseudomonas and Viridibacillus (Shivaji et al., 2011). Culture dependent phenotypic characterization and 16S rRNA gene based phylogenetic analyses were applied to study the halophilic bacterial population of the Pulikat brackish water lake, India (Sahay et al., 2011). Phylogenetic analysis of bacteria isolated from Leh cold desert led to the identification of 175 bacteria, grouped in four phyla, Firmicutes (54 $\%$ ), Proteobacteria (28\%), Actinobacteria (16\%) and Bacteroidetes (3\%), and included 29 different genera with 57 distinct species (Yadav et al., 2015a). Many different extreme environments were explored to study the diversity of Bacillus and Bacillus derived genera (BBDG) and led to the identification of 392 bacilli, grouped in two families, Bacillaceae ( 89.03 $\%$ ) and Paenibacillaceae (10.97\%), and included 13 different genera with 75 distinct species. The major outcome of the investigation was the identification of niche-specific species and also the ubiquitous presence of selected species of BBDG, which illustrate the diversity and pervasive nature of BBDG in extreme environments (Yadav et al., 2015c). Lot of attention was paid to study the diversity of Bacillus thuringiensis in different ecological niches with a primary aim to identify efficient strains against Coleopteran, Dipteran and Lepidopteran insects and also to identify strains with variability in genes coding for crystal protein (cry) (Dangar et al., 2010; Asokan et al., 2011, 2013; Das et al., 2012; Ramalakshmi and Udayasuriyan, 2010).

In the last decade efforts have been made to study the diversity of Archaea through culture dependent and independent approaches. Phylogenetic analysis of Archaea isolated from Rann of Kutch, Gujarat, India revealed a novel lineage of three isolates. The 16S rRNA sequences of the strains 3A1-DGR, H9-DGR and 2ANA-DGR showed less than 93\% similarity with the available known type strains and these three strains belong to a distinct novel lineage within the family Halobacteriaceae (Thomas et al., 2012). Using a metagenomic approach, 67 archaeal genera, representing more than $60 \%$ of all known archaeal genera, were reported from Rann of Kutch (Pandit et al., 2015). Archaea isolated from Rann of Kutch were first time reported to possess ability to solubilize phosphorus through the production of organic acids (Yadav et al., 2015d).

Many novel species of bacteria have been reported from the country. Devosia albogilva sp. nov., Devosia crocina sp. nov., Microbacterium amylolyticum sp. nov., N5T a bacterium isolated from industrial waste soil (Anand et al., 2012), Flavobacterium lin-danitolerans sp. nov., Devosia chinhatensis sp. nov., Sphingobium lactosutens sp. nov., Microbacterium lindanitolerans sp. nov., Sphingomonas histidinilytica sp. nov., Sphingobium quisquiliarum sp. nov., P25T, Sphingopyxis ummariensis sp. nov., Pseudoxanthomonas indica sp. nov., Sphingobium chinhatense sp. nov., IP26T, Sphingobium lucknowense sp. nov., Pontibacter 
lucknowensis DM9T sp. nov., Sphingopyxis indica sp. nov., Rhizobium rosettiformans sp. nov., Sphingomonas laterariae LNB2T sp. nov, Sphingobium baderi sp. nov., Edaphobacillus lindanitolerans gen. nov., sp. nov., Flavobacterium ummariense sp. nov., Acinetobacter indicus sp. nov., Novosphingobium lindaniclasticum sp. nov., Devosia lucknowensis sp. nov., Pontibacter ramchanderi sp. nov., Sphingomonas indica sp. nov., Novosphingobium barchaimii sp. nov., Sphingobium czechense LL01T, á-hexachloro cyclohexane $(\mathrm{HCH})$ degrading bacterium isolated from HCH contaminated soil (Verma et al., 2009; Kumar et al., 2008, Kumari et al., 2009, Kumari et al., 2011; Lal et al., 2010, Nigam et al., 2010; Bala et al., 2010, Dadhwal et al., 2009, Sharma et al., 2010; Garg et al., 2012; Dwivedi et al., 2013, Jindal et al., 2013, Kaur et al., 2012, 2013; Lal et al., 2012, Lata et al., 2012; Malhotra et al., 2012; Saxena et al., 2012; Devosia et al., 2013, Singh et al., 2013; Niharika et al., 2012a,b); Pseudomonas panipatensis sp. nov., Novosphingobium panipatense sp. nov., Novosphingobium mathurense sp. nov., Sphingobium abikonense sp. nov., isolated from an oil-contaminated site (Gupta et al., 2008, 2009; Kumari et al., 2009) were reported. Thermus parvatiensis $\mathrm{RL}^{\mathrm{T}} \mathrm{sp}$. nov., Lampropedia cohaerens sp. nov. and Fictibacillus halophilus sp. nov. isolated from Manikaran thermal springs were also described (Dwivedi et al., 2015, Tripathi et al., 2016, Sharma et al., 2016).

\section{Fungi}

The diversity of fungi including AM fungi and mushrooms have also been an area of interest among different workers (Swer et al., 2011; Bansal et al., 2012; Upadhyay et al., 2008; Sharma et al., 2015; Chakraborty et al., 2010a,b,c; Mesapogu et al., 2012). A total number of 1531 wild mushroom specimens were collected from forests of Himachal, Uttarakhand, Jharkhand, Chhattisgarh, Rajasthan, Arunachal Pradesh, Tripura and Andaman \& Nicobar islands. Four mushrooms, Phellodon tomentosus, Laetiporus sulphureus, Thelephora and Dictyophora were recorded for the first time in country (Upadhyay et al., 2008; Sharma et al., 2015). Two lepiotaceous mushrooms [Lepiota indica sp. nov. and Lepiota attenuispora sp. nov. (Agaricaceae)], one Limacella magna sp. nov. in the Amanitaceae and Chlorolepiota brunneotincta a new species belonging to Agaricaceae were also identified (Kumari et al., 2013; Atri et al., 2013). Diversity of culturable fungi in deep-sea sediments of the Central Indian Basin was carried out and a total of 16 filamentous fungi and 12 yeasts were isolated from 20 sediment cores indicating the presence of terrestrial fungi as a component of culturable fungi in deep-sea sediments (Singh et al., 2010). Genetic diversity and pathogenic variability among Indian isolates of Fusarium udum infecting pigeonpea (Mesapogu et al., 2012) and Macrophomina phaseolina isolates from certain agroclimatic regions of India (Babu et al., 2010) was also reported. Ambili et al., (2012) showed that arbuscular mycorhizal association and species richness was more in coconut cropping systems compared to arecanut cropping systems. Glomeraceae and Acaulosporaceae families were preponderent in both, however, Gigasporaceae was solely present in coconut cropping system. Glomus aggregatum, Funneliformis mosseae, and Rhizophagus fasiculatum were the uniformly abundant genera in both the cropping systems.

\section{Cyanobacteria}

Cyanobacteria are another group which has been extensively investigated for its diversity in different ecological niches. Distribution of toxic cyanobacteria and cyanotoxins in Lake Ambazari and Lake Phutala at Nagpur revealed the predominance of Anabaena, Oscillatoria, Lyngbya, Phormidium, and Microcystis (Maske et al., 2010). Exploration of Oscillatorian cyanobacteria of Manipur falling under Indo-Burma biodiversity hotspots was also attempted (Deepa et al., 2010). Choudhary and Bimal (2010) reported variations in the distribution of nitrogen fixing cyanobacteria in fertilized and unfertilized paddy fields. Kumar et al. (2015) carried out biochemical characterization and diversity analysis of cyanobacteria isolated from different locations. Community structure and diversity of cyanobacteria and green algae in freshwater bodies of Jodhpur, Rajasthan (Makandar and Bhatnagar, 2010a), soils of Thar Desert (India) (Makandar and Bhatnagar, 2010b), Santragachi lake, West Bengal (Ghosh et al., 2012), Bakreshwar thermal springs, Rajgiri thermal springs (Rastogi et al., 2012), high altitude lakes of Lahaul-Spiti in Himachal Pradesh (Singh et al., 2014), building facades and monuments in India (Keshari 
and Adhikary, 2013), saline soils and biological crusts on arid soils of Eastern India (Kumar et al., 2016) have been reported by different workers.

\section{Biological Nitrogen Fixation}

The major thrust in research on improving biological nitrogen fixation in legumes focussed on genetic diversity of rhizobia of major legumes grown in India including in arid and hyper-arid regions. Also efforts were made to quantify the inputs of biologically fixed nitrogen in Indian soils. The current status of biological nitrogen fixation research in India was subjected to a major review recently (Rao, 2014a)

\section{Rhizobial Diversity}

In a major initiative of the ICAR's All India Network Project on Soil Biodiversity-Biofertilizers launched in 2009, >2000 isolations of rhizobia of 20 major legumes (Chickpea, Pigeon pea, Groundnut, Cowpea, Soybean, Black gram, Mungbean, Pea, Lentil, Faba bean, Moth bean, Cluster bean, Lucerne, Berseem, Horse gram, Sesbania, Methi etc. ) were made all over India including from hyper-arid and arid regions of Rajasthan and Haryana; acid soils of Jharkhand, 'Taal' lands of Bihar, soils of Uttarakhand (Ansari et al., 2014; Gera et al., 2013; Rao, 2016) and analyzed by conventional and molecular tools. In groundnut, nodulating bacteria other than Rhizobium were identified (Enterobacter cloacae, Pantoea dispersa, Ochrobactrum). Rhizobia of arid soils showed high genetic diversity and exhibited stress tolerance and PGPR attributes. Inoculation with high temperature and drought tolerant isolates significantly improved the yields of cluster bean, mungbean and pigeonpea under rain-fed conditions. Several Rhizobium isolates of pigeon pea, chickpea and soybean in acid soils analyzed by proteomic tools, which showed unique protein differences amongst acid-soil tolerant isolates (Dubey et al., 2016 ). Garg et al. (2016) found seven biotypes of 'berseem' rhizobia in Haryana soils of which two types were common in three districts showing some degree of endemism even in the high temperature arid soils.

The population of soybean-rhizobia and the proportion of slow and fast growers were enumerated in Vertisols of central India in different crop rotations. Soybean based rotations stimulated the rhizobial population by 22 fold as compared to cereal rotations
(Kumar et al., 2017). Lowest rhizobial populations were in the summer and re-bounded after rainy season at maximum vegetative growth by 13.3 fold in soybean rotations but only 1.7 fold in cereal rotations. Long term integrated nutrient management by annual application of farm yard manure in soybean along with chemical fertilizers improved the rhizobial numbers by 1.5 fold over chemical fertilization alone and by 2.9 fold over unfertilized treatments. Increased crop growth by chemical fertilizers also stimulated rhizobial populations by 1.9 fold over unfertilized soybean. The slow growing bradyrhizobia were symbiotically superior to the fast growing rhizobia but their proportion was lower in soybean based rotations as compared to cereal based rotations. Results highlight the importance of crop rotation with cereals, application of organic amendments along with chemical fertilizers and selecting slow growing rhizobia as inoculants.

\section{BNF Quantification}

Measurements of legume BNF in long term field experiments are very few in India. Rawat et al. (2013) in a 8 year soybean-wheat rotation experiment in Vertisol showed that fertilized and uninoculated soybeans (nodulated by native rhizobia) removed 158 $\mathrm{kg} \mathrm{N} \mathrm{ha}^{-1}$ (1.8 $\mathrm{Mg} \mathrm{ha}^{-1}$ seed yield) whereas fertilized and inoculated soybeans removed $173 \mathrm{~kg} \mathrm{~N} \mathrm{ha}^{-1}$ for a $2.0 \mathrm{Mg} \mathrm{ha}^{-1}$ seed yield and BNF amounted to $\sim 92-$ $100 \mathrm{~kg} \mathrm{~N} \mathrm{ha}^{-1} \mathrm{yr}^{-1}$. The soil $\mathrm{N}$ increment in $0-15 \mathrm{~cm}$ soil was $27.8 \mathrm{~kg} \mathrm{ha}^{-1} \mathrm{yr}^{-1}$ after soybean harvest and $33.2 \mathrm{~kg} \mathrm{~N} \mathrm{ha}^{-1} \mathrm{yr}^{-1}$ after wheat harvest in the fertilized uninoculated plots averaged over eight years. In the fertilized and inoculated plots (Bradyrhizobium to soybean and Azotobacter to wheat) the soil N increments were 40.8 and $34.0 \mathrm{~kg} \mathrm{~N} \mathrm{ha}^{-1} \mathrm{yr}^{-1}$ after soybean and wheat harvest respectively.

\section{Gross Estimate of BNF in India}

Worldwide production of nitrogenous fertilizer through Haber-Bosch process is about $120 \mathrm{Tg} \mathrm{yr}^{-1}$. It may reach $165 \mathrm{Tg} \mathrm{yr}^{-1}\left(1 \mathrm{Tg}=1\right.$ million tonnes or $\left.10^{9} \mathrm{~kg}\right)$ by 2050 , bringing with it all the attendant environmental consequences, particularly the increased production of reactive nitrogen species $(\mathrm{Nr})$ and nitrate leaching to ground-water. Cultivation of crops adds $\mathrm{N}$ inputs though biological nitrogen fixation (BNF) amounting to $55-60{\mathrm{Tg} \mathrm{yr}^{-1}}^{-1}$. By adopting the agricultural cropping 
area data of 2014, total $\mathrm{N}$ harvest and Ndfa (nitrogen derived from air), the BNF input added by various crops of India was estimated at $5.2 \mathrm{Tg} \mathrm{yr}^{-1}$ by Rao and Balachandar (2017). Of this, legumes added 2.24 $\mathrm{Tg}$ (pulses 0.94 ; soybean 0.80 and groundnut 0.50 $\mathrm{Tg}$ ); major cereals added $1.51 \mathrm{Tg}$ (rice 0.76 ; wheat 0.65 ; maize $0.10 \mathrm{Tg}$ ); coarse cereals $0.13 \mathrm{Tg}$; sugarcane $0.20 \mathrm{Tg}$; fodder legumes $0.55 \mathrm{Tg}$; $\mathrm{N}$ fixing and other trees $0.41 \mathrm{Tg}$ ). A conservative estimate of $\mathrm{BNF}$ in Indian agriculture was computed as 5.20 to $5.76 \mathrm{Tg}$ (9.5 to $10.6 \%$ of global agricultural BNF).

\section{Soil Biological Health}

\section{Soil Health Indicators}

Soil microbiome is a sensitive indicator of soil health as it provides an indication of the direction and magnitude of the changes in ecosystem structure and function, earlier and better than others. Soil microbial biomass, respiration and soil enzyme activities have been extensively used to assess soil health in the past. Rao (2013) reviewed the worldwide and Indian literature on soil biological health and concluded that measurements of organic carbon, labile carbon, soil respiration, population of diazotrophs, soil dehydrogenase activity, soil enzymes like â-glucosidase and acid phosphatase, and glomalin content are easy to measure routinely and give a good idea of soil health. All are related to each other and are of the 'more is better' type.

Genomic indicators of soil health have now been developed in last five years. In a 100-year old permanent manurial trial at Coimbatore continuous application of organic manures enhanced the abundance of members of phyla Acidobacteria and Actinobacteria, while the balanced inorganic fertilization induced minimal shift in the bacterial community composition of semi-arid tropical Alfisol (Chinnadurai et al., 2014). The consequences of agricultural intensification with fertilizers and pesticides in Vertisols of Guntur, Andhra Pradesh showed differential effects in chilli and black gram. Very high inputs in chilies had an adverse effect on soil biological properties but not in black gram. In chilies, the counts of copiotrophs increased, of fungi and Actinobacteria reduced significantly, â- glucosidase activity increased and acid phosphatase activity reduced with very high inputs (Aparna et al., 2016). Metagenomic analysis of $16 \mathrm{~S}$ rRNA gene showed a drastic reduction in the diversity of bacteria that was represented by only three phyla in very high input soils of chilli, whereas in normal there were 12 phyla (Malhotra et al., 2015). The proportion of Actinobacteria reduced from 30\% in normal to $14 \%$ in very high input soils. The phylogenetic diversity of bacteria did not reduce in high input soils of black gram but was altered. No significant reduction in proportion of Actinobacteria was observed. The proportion of rhizobial nifH in black gram soil was reduced by $46 \%$ due to high inputs compared to normal inputs. Methods for measurement of soil biological health should therefore emphasize the size of Actinobacteria. In organically farmed Aridisols of Rajasthan, there was increase in counts of copiotrophs, oligotrophs, actinobacteria, higher content of glomalin (a measure of vesicular arbuscular mycorrhizal fungi), dehydrogenase activity, acid phosphatase, fluorescein diacetate hydrolysis and âglucosidase. The eubacterial diversity analysis by sequencing of metagenomic DNA using next generation sequencing technologies showed Actinobacteria were $10 \%$ higher in organic and Proteobacteria were $20 \%$ higher in proportion in conventional management. The relative proportions of Actinobacteria and Proteobacteria thus serves as a good indicator of soil biological heath (Rao et al., 2014).

Studies on the impact of long term nutrient management in a 100 year old permanent manurial trial in a semi-arid Alfisol showed that soils under organic management had significantly higher microbial biomass carbon, total culturable bacterial counts and Azotobacter populations, whereas the chemical fertilized and unfertilized soils were similar. Though Azotobacter populations were higher in organic soils, however the genetic diversity was similar in all three soils (Cinnadurai et al., 2013). Apart from nutrient management, cropping pattern and crop growth stages also influence the soil microbial dynamics by altering the temporal and spatial distribution of available substrates from rhizodeposition and root biomass (Tamilselvi et al., 2015). All the assessments revealed that the active vegetative stage irrespective of crops tested recorded more abundance of diversified rhizodeposits which significantly favoured the microbial colonization and diversity.

The role of soil microfauna as indicators of soil health has received little attention. Highest mean 
abundance of Collembola at different vegetational sites in Varanasi, (belonging to 18 genera that were identified) were found in floral garden (24\%) and least in grassy field (16\%), with mango orchard, bamboo grove and teak plantation being intermediate (20\%) (Raghuraman et al., 2010). In a study in northeast India at the AAU, Jorhat Centre of the ICARAll India Network Project on Soil BiodiversityBiofertilizers, Collemobolans sampled throughout the year were highest in forest followed by fallow land and were the least in agro-ecosystem (Assam Agricultural University 2016). Collembola and mites were the highest in soils from pristine forest followed by organically cultivated vegetables, rice grown with integrated nutrient management whereas least were in paddy cultivated with conventional chemical fertilization. (Assam Agricultural University 2014).

In a study in hill ecosystem of Nagaland, metagenomic analysis of soils showed that soils with shorter jhum cycle (slash and burn cultivation) of 5 years had greater bacterial and archaeal abundance coupled with lesser eukaryotic abundance in comparison with a longer fallow cycle of 20 years (Thakuria and Sharma, 2014). Longer fallow cycle sites had greater woody plants, perennials and bryophytes; peroxidases and pectin esterases as the most exclusive enzymes; and led to a more stabilized $\mathrm{N}$-sufficient ecosystem. This study demonstrated clearly the role of the regenerated above-ground vegetation during fallow phase in shaping the soil biodiversity and thereby regulating the ecosystem processes for stabilizing the ecosystem.

\section{Practices to Improve Soil Health}

Sustainable agriculture should manage the natural resources so as to maximize yield output with use of minimal synthetic inputs. Sustainable intensification of production should be achieved without any longterm detrimental effect on microbial communities. Some important research findings on management practices that impact soil microbial diversity and functioning are discussed here.

In a field experiment on a sandy loam soil in north India on wheat, conservation tillage significantly increased soil respiration, soil microbial biomass carbon and soil dehydrogenase activity compared to conventional tillage (Sharma et al., 2011). Similarly, in a field study on four tillage practices in NE India on rice-wheat/mustard/linseed, zero tillage (residue retention and double no-till) recorded higher SMBC, dehydrogenase activity and earthworm population, which in turn resulted in good growth and higher yield of all the crops (Ghosh et al., 2010).

A number of studies have reported beneficial effects of applying balanced dose of chemical fertilizers on crop productivity, soil organic matter and biological properties [for review see Rao (2013)]. The impact of application of animal manures, sewage sludges, composts and other organic amendments on changes in microbial properties of soil is welldocumented. These amendments increase the size, activity and diversity (Chinnadurai et al., 2014) of soil microbial communities. Such enhancements have the benefits for crop productivity through increased nutrient cycling rate and impact climate change (Kollah et al., 2014).

Recent awareness of organic farming has made the recycling of agro-wastes an integral part of resource management. Managing the crop residues using microbial technology is beneficial; microorganisms producing hydrolytic enzymes e.g., laccase, peroxidase, polyphenol oxidase, cellulase, xylanase etc. are now being increasingly deployed. Thermophilic lignolytic and cellulolytic fungi, bacteria and actinobacteria such as Trichoderma viride, $T$. reesei, Phanerochaete chrysosporium, Aspergillus niger, A. nidulans, A. awamori, Streptomyces spp., are being successfully demonstrated as inoculants for rapid decomposition of paddy straw, wheat straw, jowar, pearl millet stover as also urban solid wastes (Manna et al., 2014). For microbial enrichment of compost, after the thermophilic phase of composting is over, $\mathrm{N}$ fixers and $\mathrm{P}$ solubilizers are added e.g., Azotobacter, P solubilizing fungi Aspergillus awamori to enrich available $\mathrm{N}$ and $\mathrm{P}$. Addition of rock phosphate $(12 \%)$, pyrite $(10 \%)$, urea $(1 \%), \mathrm{ZnSO}_{4}(0.1 \%)$ were also found useful for hastening the decomposition of crop residues as well as nutrient balancing of organic amendments. A consortium of four efficient lignocellulolytic psychrotrophic microbes (Eupenicillium crustaceum, Paceliomyces sp., Bacillus atropheus and Bacillus sp.) and commercial fungal consortia (Aspergillus awamori, Aspergillus nidulans, Trichoderma viride and Phanerochaete chrysosporium) were used to enhance the composting process of paddy straw at low temperature 
(Shukla et al., 2016). The potential of two epigeic earthworms (Perionyx excavatus and Eisenia foetida) was compared for composting of crop residues (wheat straw and paddy straw) amended with farm yard manure. In general, $P$. excavatus exhibited better growth and mineralization efficiency, which further support the suitability of the species for large scale vermiculture operations (Singh et al., 2014). Another variation was to develop cyanobacteria fortified compost that was demonstrated as viable inoculation option for integrated nutrient and pest management strategies of cotton (Dukare et al., 2011, Prasanna et al., 2014).

\section{Microbial Inoculants}

The use of microbial inoculants in sustainable agriculture has been shown to reduce the inorganic fertilizer inputs (nearly 25\%), improve the nutrient use efficiency of various inorganic fertilizers under integrated nutrient management and also the quality of the produce (Rao, 2014b) and soil health (Aparna et al., 2014). The microbial inoculant based integrated nutrient management (INM) practice (Azospirillum, Rhizobium and phosphate-solubilizing bacteria and fertilization with rock phosphate rock, compost, and muriate of potash) on rice-legume-rice rainfed production system in Assam reported significantly better cumulative grain yield, N, P and Zn uptake with positive $\mathrm{N}$ balance in soil than farmer's practice (Thakuria et al., 2009). The mechanisms by which plant growth promoting rhizobacteria improve plant health has been reviewed by Dutta and Podile (2010). Increased soil aggregates, better fungal/bacterial biomass $\mathrm{C}$, high number of earthworm casts and high degree of bacterial community diversity are the other significant impacts reported in those soils used with microbial inoculants. In North-east India, in rice-rape seed rotation for two years soil health as reflected in soil enzyme activities were highest when fertilizers, composts and biofertilizers were added together (Nath et al., 2012).

\section{Mitigation of Stresses}

Saravanakumar et al. (2011) have reported the ability of $P$. fluorescens Pf1 to increase the activity of catalase and peroxidase in water stressed green gram plants when compared to untreated plants. The bacterized plants were found to tolerate stress better than the uninoculated controls. Ali et al. (2011) reported that inoculation of plant growth promoting thermotolerant Pseudomonas putida improved the survival and growth of wheat plants under heat stress. Inoculation reduced membrane injury and the activity of several antioxidant enzymes such as SOD, APX and CAT under heat stress. Inoculation improved the levels of cellular metabolites like proline, chlorophyll, sugars, starch, amino acids, and proteins compared to uninoculated plants. Scanning electron microscopy studies confirmed the colonization of the organism on the root surface. Psychrotolerant Pseudomonas spp. exhibiting plant growth-promoting activities at $4^{\circ} \mathrm{C}$ were inoculated and found effective in cold alleviation and promoting growth nutrients uptake of wheat seedling at $8^{\circ} \mathrm{C}$ (Mishra et al., 2011). Bacterization significantly improved the level of cellular metabolites and other physiological attributes involved in cold alleviation. These results suggest the possible role of microorganisms in mitigating adverse effects of climate changes on crop growth and may lead to development of microbe based climate-ready technology.

The ability of the rhizobacterial strain Pseudomonas putida GAP-P45 to improve the plant biomass, relative water content, leaf water potential, proline sugars, and free amino acids of maize plants exposed to drought stress was recently reported by Sandhya et al. (2010). Methylobacterium commonly referred as pink-pigmented facultative methylotrophs (PPFM) are phyllosphere dwelling proteobacteria and have the ability to induce the systemic tolerance to drought through ACC deaminase enzyme (Chinnadurai et al., 2009). By spraying this bacteria under large scale $(24,000$ litres covering 1.25 lakh ha of rice crop), the short-term drought tolerance (for about 15 days) was induced in rice, which avoided the complete yield loss due to monsoon failure in 201112 in Tamil Nadu Cauvery delta area (K. Ilamurugu, Personal communication). In another study coinoculation of B. subtilis and Arthrobacter sp. could alleviate the adverse effects of soil salinity on wheat growth (Upadhyay et al., 2012). Inoculation with salinity tolerant Azotobacter strains has also been reported to significantly increase total nitrogen, biomass and grain yield of wheat in saline soils (Chaudhary et al., 2013). These findings provide a new dimension in inoculant technology for mitigating drought stress which is so crucial in this era of climate vagaries. Halotolerant bacteria Bacillus and 
Halobacillus spp. mitigated salt stress on wheat growth and enhanced plant growth even at very high salinity (Ramadoss et al., 2013) and would thus be most appropriate as bioinoculants under such conditions. Psychrotolerant Pseudomonas was found effective against Cajanus cajan and Eleusine coracana (Shukla et al., 2015).

Subhashini (2012) reported the biocontrol potential of Streptomyces spp. isolated from tobacco rhizosphere and also its bioherbicidal activity (Subhashini 2014). Six strains of Streptomyces sp. with proven potential for plant growth-promotion (PGP) in rice were also found effective on chickpea and enhanced nodule number and biomass; root and shoot biomass, stover and grain yield and soil dehydrogenase activity and mineral nutrients (Gopalakrishnan et al., 2015). Scanning electron microscopy revealed the success in colonization of the chickpea roots by all six strains. Bacterial wilt caused by Ralstonia solanacerum in tomato was significantly reduced by $>60 \%$ by application of lactic acid bacteria as biocontrol agent through seed treatment as well as soil drench (Murthy et al., 2013). Bacillus amyloliquefaciens was found to be the best PGPR for growth promotion and management of soft rot disease in ginger (Dinesh et al., 2015). A single strain multi-functional PGPR-Bacillus licheniformis was found to control white root rot disease of apple caused by Dematophora necatrix and improve plant health, vigour and fruit yield in both diseased and healthy orchards in Himachal Pradesh (YSPUHF, 2014). Trichoderma has achieved significant success as a powerful biocontrol agent at global level; Keswani et al. (2014) reviewed the potential applications of target specific secondary metabolites produced by different species of Trichoderma for controlling phytopathogens and their applications in diverse areas with the major emphasis on agriculture.

\section{Plant Microbe Interactions}

Plant-microbe interaction studies employing nitrogen fixers, PSBs, PGPRs and AM fungi were carried out in several laboratories. Two strains of Gluconacetobacter diazotrophicus isolated from endorhizosphere of sweet sorghum (Acd1 and Acd2) were tested for their plant growth potential and nitrogen-fixing ability along with a reference strain obtained from Brazil (Pal3) under green house and field conditions with sweet sorghum cultivar PC 121 in the presence of fertilizer nitrogen (20 and $40 \mathrm{~kg} \mathrm{~N}$ $\mathrm{ha}^{-1}$ ) applied in the form of isotopically labelled ammonium sulphate $\left[\left({ }^{15}\left(\mathrm{NH}_{4}\right)_{2} \mathrm{SO}_{4}\right]\right.$ (Sahai et al., 2015). Priya et al. (2015) studied the influence of cyanobacterial inoculation on the culturable microbiome and growth of rice. Many reports on the inoculation of PGPR along with Rhizobium were published (Tsigie et al., 2011). Co-inoculation of the endophytic fungus Piriformospora indica with the phosphate-solubilising bacterium Pseudomonas striata was shown to influence the population dynamics of $P$. striata and also growth of chickpea (Meena et al., 2010). Dudeja et al. (2012) reviewed the work on legume endophytes; the quantum benefit derived by plants from an endophyte and vice versa is still unclear and it is still not clear which population of microorganisms (endophytes or rhizospheric) promotes plant growth and the way the interactions among endophytes influence plant productivity. Suman et al. (2016) reviewed the mechanism by which endophytes contribute to better plant health. Bhattacharjee et al. (2012) reported the beneficial effect of an IAA and ACC deaminase-producing Rhizobium leguminosarum bv. trifolii in promoting rice growth. Gosal et al. (2012b) isolated several nitrogen fixing bacteria in wheat rhizosphere in Punjab soils and using molecular methods characterised them as Azotobacter sp., Azospirillum sp., Stenotrophomonas maltophilia, Stenotrophomonas sp., Sphingomonas paucimobilis, Rhizobium larrymoorei, Pseudomonas aeruginosa, and Xanthomonas oryzae. Inoculation of sugarcane with Azotobacter in Punjab soils gave increase in cane yield of 3-4 $\mathrm{Mg} \mathrm{ha}^{-1}$ (Gosal et al., 2012a). An endophytic Bacillus sp. was found very effective in promoting sugarcane yield under field conditions at Pantnagar (Chauhan et al., 2013). Saini et al. (2015) isolated endophytes from chickpea, Bacillus subtilis and Bacillus licheniformis; there was more diversity in nodule endophytes than root endophytes, they could solubilize phosphate and could promote growth of chickpea in field better than recommended biofertilizers. PGPR, Bacillus megaterium from coconut and Pseudomonas putida from cocoa were found cross-compatible with vegetables crops like chili and tomato (Rajeela et al., 2017).

Phosphate-solubilizing microorganisms from salt-affected soils of India were reported to 
significantly influence the growth of sorghum plants (Srinivasan et al., 2011). Besides P solubilising bacteria, phytase producing bacteria have been implicated in influencing the growth and phosphorus uptake of Indian mustard (Brassica juncea) (Kumar et al., 2013). Potassium solubilising bacteria Bacillus subtilis and Bacillus megaterium were shown to reduce the $\mathrm{pH}$ and also produce exopolysaccharides and promote the growth of elephant foot yam in field (Anjanadevi et al., 2016). Bacteria with plant growth activities were identified in wheat rhizosphere in different agro-climatic zones of India belonging to Bacillus, Exiguobacterium, Lysinibacillus, Paenibacillus etc., that could be promoted niche-specific inoculants for crops growing in respective climatic conditions. (Verma et al., 2016a) Several thermo-tolerant bacterial isolates exhibiting plant growth promoting attributes at high temperature were isolated (Verma et al., 2016b) and may have application as inoculants for plant growth promotion and biocontrol agents for crops growing at high temperature conditions. The potential of eight thermotolerant bacteria (seven Bacillus spp. and one actinobacterium Kocuria sp.) and two cyanobacteria (Anabaena laxa and Calothrix elenkinii) as plant growth promoting (PGP) agents was evaluated with seed spices coriander, cumin and fennel, under controlled conditions in potting mix fortified with microbial cultures (Kumar et al., 2013a). Application of mycorrhiza associated bacteria like Pseudomonas putida with Glomus mosseae significantly increased the mycorrhizal colonization and growth of sapota and helped in establishment of healthy seedlings which has a large impact on establishment of seedlings and germplasm maintenance (Panneerselvam 2013).

Microbes have also been used for biofortification of micronutrients in crops like soybean and wheat. Biofortification of wheat through inoculation of plant growth promoting rhizobacteria and cyanobacteria has also been reported (Rana et al., 2012). Inoculation of zinc solubilizing Bacillus aryabhattai strains has been reported for mobilization and biofortification of zinc in soybean and wheat (Ramesh et al., 2014). Two endophytes Arthrobacter sulfonivorans DS-68 and Enterococcus hirae DS-163 efficient for fortification of Fe and two endophytes Bacillus subtilis DS-178 and Arthrobacter sp. DS-179, efficient for fortification of $\mathrm{Zn}$ in low accumulator wheat genotype were identified. In general, the amount of $\mathrm{Zn}$ in grains due to inoculation of endophytes was 2 folds higher as compared to un-inoculated control (Singh et al., 2017). Many plants engage in interactions with rhizosphere- and root-associated microbes to survive in toxic and nutrient-limited environments. Abhilash et al. (2012) have given examples of how plants and their associated microbes can be screened, custombuilt and utilized in field applications.

\section{Biofertilizer Technology}

Solid carrier based (peat or lignite) inoculants are used in most tropical countries, including India but they have several drawbacks like a short shelf life, high contaminants and inconsistent field performance. In India, several liquid formulations containing not only the desired microorganisms and their nutrients but also added cell protectants or chemicals that promote formation of resting spores or cysts have been developed (Trimurtulu and Rao, 2014). Several pulse crops responded well to the application of liquid inoculants than carrier inoculants and the response was better in Alfisols than in Vertisols. In cereal crops like rice, maize and wheat, liquid inoculants enhanced the grain yields over local carrier inoculants and resulted in $25-30 \%$ saving of chemical fertilizers. Liquid inoculants of good quality thus hold a great promise to farmers of tropical countries.

A microbial consortium package consisting of Pseudomonas-enriched mycostraw, Azospirillum, and cyanobacteria used in rice for four years resulted in an increase in organic carbon, preponderance of Azospirillum in soil, nitrogen fixation, total $\mathrm{N}$ and $\mathrm{P}$ and fertilizer use efficiency and rice yields in gangetic alluvial soils (Jha et al., 2013).

A novel strategy of developing multifunctional inoculants in the form of biofilms using a combination of two organisms with useful plant growth-promoting rhizobacteria (PGPR) was optimized. Trichoderma and Anabaena was employed as matrix and agriculturally important bacteria (Azotobacter chroococcum, Pseudomonas fluorescens and Bacillus subtilis) as partners (Prasanna et al., 2010; Triveni et al., 2012b). The synergism in terms of the PGP traits in the biofilms revealed their promise as superior PGP inoculants as compared to the individual organisms and dual cultures (Triveni et al., 2012c; Prasanna et al., 2013). Different carriers were used 
to develop the formulations of biofilmed inoculants (Triveni et al., 2012a). The influence of biofilmed formulations composed of Trichoderma viride and Anabaena torulosa as matrices was investigated in Macrophomina phaseolina infected cotton crop, in terms of plant growth and biocontrol parameters (Triveni et al., 2015). These biofilms were tested with several crops like cotton, wheat, chickpea and soybean and recorded increase in growth and yield (Swarnalakshmi et al., 2013; Prasanna et al., 2014). Anabaena based biofilms were found effective in improving micronutrient uptake in rice (Adak et al., 2016).

Mesorhizobium ciceri-based biofilms were developed and used for the antifungal and plant growth promoting activity in chickpea challenged Fusarium wilt (Das et al., 2017). These studies illustrates that such biofilms may closely mimic natural microbial communities and may represent a more viable inoculation option for integrated pest and nutrient management strategies in agriculture.

\section{Soil Pollution and Bioremediation}

Less than $1 \%$ of total applied pesticides generally get to the target pests while most of it remains unused, which causes serious ecological problems. The use of chemical pesticides played an important part in the green revolution in India but environmental concerns about the harmful consequences have led to design of newer molecules, transgenic plants etc., which have addressed some of the concerns. High inputs of pesticides are damaging and leads to loss of diversity and/or function within the soil microbial community. Over the past 15 years, use of microorganisms has shown promise in remediation of soil pollutants which include organic compounds, heavy metals, hydrocarbons, poly-chlorinated aromatic compounds and so on. Pesticide degradation may be carried out by several ways described as biotransformation, biomineralization, bioaccumulation, biodegradation, bioremediation and co-metabolism. Microbial degradation involves the use of effective microbes for pesticides belonging to organochlorines, organophosphorus or carbamate groups. Because of the tropical nature of the Indian environment and the varied ecology under which various crops are grown, Indian agro-ecosystem remains a rich source of diverse microorganisms expressing such potential of detoxification. Over the years, concept of microbial degradation of xenobiotics has taken strong roots and with the extension of knowledge, biochemical and genetic basis of biodegradation are being worked out. During the last two decades, substantial information on the microbial degradation of several pesticides was generated from various laboratories in India. Recent reports involve the isolation and screening of many microbes for degradation of xenobiotics. Of these many agriculturally important species have been reported to be involved in the degradation of Atrazine (Sagarkar et al., 2013; Kolekar et al., 2014; Bhardwaj et al., 2015; Dutta et al., 2016); Chlorpyrifos ( Lakshmi et al., 2009; Sasikala et al., 2012; Maya et al., 2011; Dubey and Fulekar, 2012; Abraham and Silambrarasan, 2013; Maya et al., 2012; Silambarasan and Abraham, 2013; Silambarasan and Abraham, 2014 and Pailan et al., 2015); 2,4-D and phenoxy herbicides (Gauri et al., 2012; Singh, 2013); DDT (Bajaj et al., 2014a); Endosulfan (Jesitha et al., 2015; Singh and Singh, 2011; Bajaj et al., 2014b; Giri and Rai, 2012.) and monocrotophos (Jain et al., 2014; Acharya et al., 2015); Hexachlorocyclohexane (Negi et al., 2016); Nitroaniline, Nitrophenols, Phorate and Phenylurea herbicides. Formulation of bacterial and fungal consortia effective in biomineralisation of pesticides have been reported along with optimisation of conditions for degradation (Abraham and Silambarasan 2014, Bhattacharjee et al., 2014). Pesticide degradation genes of several bacteria are usually located in extrachromosomal genomes and encode the degrading enzymes. This has allowed the development of bioremediation technology based on engineered microbes. Also, scientists are planning to transfer the genetic potential of pesticide degradation in other microbes to effectively utilize their potential in the safe disposal of xenobiotic residues.

Genetically engineered or modified crops (GM crops) give superior yields with less use of pesticides but their effects on non-target organisms including soil microbial communities are the major risks. Balachandar et al. (2008) recorded no significant difference in the community composition of pinkpigmented facultative methylotrophs (PPFMs) between Bt- and non-Bt cotton. Soil respiration, dehydrogenase and mineral nitrogen were reduced in Bt-cotton soils while microbial biomass carbon and nitrogen and phosphatase showed an increased trend compared to non-Bt cotton (Sarkar et al., 2008; Sarkar 
et al., 2009).

Agricultural soils are polluted due to a variety of point and non-point sources. Tripathi et al. (2013) assessed the effects of application of long term application (2 decades) of pulp and paper mill effluent on bacterial diversity and found no adverse effects, rather there was an increase in diversity. Of various sources of pollution, the one issue that needs firm attention is heavy metal pollution because they do not degrade or disappear and can only be transformed from one oxidation state to another of lower solubility. Indiscriminate release of heavy metals such as cadmium, copper, lead, nickel, zinc etc. from various sources including fertilizers, urban solid wastes etc., into soil and aquatic environments has altered their geochemical cycles and biochemical balance. Heavy metals adversely affect soil respiration, microbial activity and soil enzyme activity, inhibit nutrient transformation processes such as ammonification and nitrification, reduce earthworm population, suppress algal population, crops yields and quality, soil microflora and cause health problems through accumulation in food chain (Adhya and Pathak, 2013). The bacteria showing resistance to heavy metal toxicity posses specific genes for that and there is evidence that organic farming can enhance proportions of those genes in rhizosphere (Rao et al., 2014). Bacterial inoculation can alleviate metal toxicity (Aluminium) of crop plants in polluted soils (Thakuria et al., unpublished). Researches on heavy metal bioremediation, have been fewer. While some studies were on heavy metal removal through microbial films including fungal biomass (Joshi et al., 2011), majority research has focussed on surfactant producing microbes. Elevated atmospheric $\mathrm{CO}_{2}$ enhance the biomass production and metal accumulation in plants and influence the plant-microbe-metal interaction in polluted soils (Rajkumar et al., 2013).

\section{Microbiology of Climate Change}

Increased emissions of GHGs viz., carbon dioxide $\left(\mathrm{CO}_{2}\right)$, methane $\left(\mathrm{CH}_{4}\right)$ and nitrous oxide $\left(\mathrm{N}_{2} \mathrm{O}\right)$ are anticipated to raise the mean ambient global temperature by $2^{\circ} \mathrm{C}$ by 2050 causing a change in the global climatic patterns, and thereby, affecting the life systems on the planet (IPCC, 2013). Alternately, increased temperature and elevated $\mathrm{CO}_{2}$ would result in an increased emission of GHGs, especially $\mathrm{CH}_{4}$.
Incidentally soil microorganisms including heterotrophs-autotrophs, methanogens-methane oxidizers and nitrifier-denitrifiers present in the environment are responsible for the production and consumption of these greenhouse gases in the environment. Most of the microbiological processes such as respiration, methanogenesis, nitrification and denitrification are significantly enhanced due to climatic change.

Studies including both culture-based and nonculture-based methods have helped in the characterization of GHG-cycling microbial population and their dynamics. Molecular methods have emerged successful in the identification and characterization of methanogens in many rice field ecosystems (Singh and Dubey, 2012; Singh et al., 2012; Dubey et al., 2013). The RFLP-based 16S rRNA gene-targeted phylogenetic analysis showed that clones obtained from rhizospheric rice soils were closely related to diverse group of methanogenic community represented by Methanomicrobiaceae, Methanosarcinaceae, Methanosaetaceae and RC I (Singh and Dubey, 2012; Singh et al., 2012). Following flooding of the rice fields, the fermentation of polysaccharides leads to the formation of $\mathrm{H}_{2}$, acetate and other fermentation products. At this stage, hydrogenotrophic methanogens belonging to Methanocellales, Methanomicrobiaceae and Methanobacteriaceae are found to be more active (Dubey et al., 2013). Methanocellales are found to be the more preferred methanogenic archaea in Indian paddy fields in both oxic as well as anoxic soils during plantation of rice crop, thereby contributing a more active role in methane production (Singh and Dubey, 2012; Dubey et al., 2014).

As the earth's climate and GHG cycling are considered closely linked climatic changes including increased temperature and elevated $\mathrm{CO}_{2}$, may also contribute to increased $\mathrm{CH}_{4}$ emission, and changes in the methanogenic microflora). Elevated $\mathrm{CO}_{2}$ concentration favoured methanogenesis under field conditions involving rice paddy, attributable to the decrease in the abundance of methanotrophs (Das and Adhya, 2012) as also selective stimulation of specific methanogenic population. Based on whole genome metagenomic approach, four methanogenic genera (Methanobacterium, Methanosphaera, Methanothermus and Methanothermococcus) 
were found to be absent under ambient $\mathrm{CO}_{2}$ concentration, contrary to their presence at elevated $\mathrm{CO}_{2}$ level (Bhattacharyya et al., 2016). However, not many studies involving nitrifier-denitrifiers under field situations including their diversity and dynamics have not been worked out under Indian conditions, excepting a few related to sewage treatment plants.

In simulated experiments an increase in methane concentration in atmosphere resulted in a doubling of apparent $\mathrm{CH}_{4}$ consumption rate (Mohanty et al., 2016). Methanotrophs and heterotrophs increased and there was increase in potential denitrification rate, potential iron and sulfate reduction rate. Methane feedback cycle influenced composition of the methanotrophs community. Methane uptake in soils of soybean-wheat production system under different fertilization regimes in Vertisol showed that it was higher in organic, followed by integrated nutrient management and least in inorganic management irrespective of the crop (Mohanty et al., 2015). Result highlighted that organic farming can significantly decrease global atmospheric $\mathrm{CH}_{4}$ budget in addition to improving soil physical and biological properties. Kollah et al., (2015) showed that biochar enhanced the methane consumption potential in tropical Vertisols, particularly smaller sized fractions $(<0.25 \mathrm{~mm})$, and could be an effective strategy to mitigate atmospheric $\mathrm{CH}_{4}$. Organic amendments like vermicompost and FYM were more effective than poultry manure in improving methane consumption in soils. But when combined with biochar poultry manure was most effective in improving the population of methanotrophs.

\section{Conclusions and Future Needs}

There is now a large repository of microorganisms available for deployment for improving plant growth, nutrition and mitigating abiotic and biotic stresses. Improvement of soil biology is the key to improving soil health. The effects of crop and soil management on the soil microbial community and functionality are well studied. Microbial inoculants are now playing an important role in organic and sustainable agricultural systems. The application of microbial technologies for recycling of municipal, industrial and agricultural wastes is getting popular. It is also being extended for remediation of polluted soils. Some areas requiring more attention in future are:
- Improve the methods of isolation so as to bring a greater proportion of the unculturables into culture. Explore the role of Acidobacteria in soil functionality.

- Unravel the role of archaea in maintaining soil health and sustainability and how their activity can be modulated.

- Research the role of soil fauna in nutrient turnover, improving soil and crop productivity in various agricultural situations and practices, an area which continues to be neglected by soil microbiologists.

- Research the methods to improve soil organic matter formation by heterotrophic microorganisms and improve soil carbon sequestration.

- Understand the exact mechanisms by which PGPR alter the physiology and immune system of plant and improve the fitness to withstand biotic and abiotic stresses.

- A deeper understanding of the deleterious rhizobacteria and fungi is needed to understand the mechanisms that lead to pathogen build-up in various unsustainable agricultural practices.

- Identification of the factors that disturb the right balance between the proportion of the beneficial and deleterious microorganisms will be a major area of research that will allow microbiologists and plant breeders to 'tailor' crop varieties in a way to ultimately benefit soil health through rhizosphere engineering.

- Widen the search for more efficient consortia of mineral solubilizing microbes from organic and inorganic native forms, for meeting the deficiency of P, S, Zn etc. and preparation of organo-mineral-biofertiliser preparations.

- More emphasis on improving the inputs of symbiotic nitrogen fixation by legumes through improved rhizobial selection to maximise BNF contribution in the era of climate change.

- Develop one or two sensitive, compound indicators of soil biological health, easily measurable, cost-effective and amenable to rapid automation (based on soil respiration or 
genes/gene transcripts). It is a potentially exciting goal and challenge so that scientists can use it in a practical way for advisory purpose on soil health akin to soil testing for soil fertility.

- Quantification of ecosystem services rendered by microbes.

The tremendous advances in agricultural microbiology in last two decades in India are clearly attested to by the discovery of dozens of

\section{References}

Abhilash P C, Powell, J R, Singh H B and Singh B K (2012) Plant-microbe interactions: novel applications for exploitation in multipurpose remediation technologies Trends in Biotechnol 30 416-420

Abraham J and Silambarasan S (2013) Biodegradation of chlorpyrifos and its hydrolyzing metabolite 3,5,6trichloro-2-pyridinol by Sphingobacterium sp. JAS3. Process Biochem 48 1559-1564

Abraham J and Silambarasan S (2014) Biomineralization and formulation of endosulfan degrading bacterial and fungal consortiums. Pestic Biochem Physiol 116 24-31

Acharya K P, Shilpkar P, Shah M C and Chellapandi P (2015) Biodegradation of Insecticide Monocrotophos by Bacillus subtilis KPA-1, Isolated from Agriculture Soils. Appl Biochem Biotechnol 175 1789-1804

Adak A, Prasanna R, Babu S, Bidyarani N, Verma S, Pal M, Shivay YS and Nain L (2016) Micronutrient enrichment mediated by plant-microbe interactions and rice cultivation practices J Plant Nutr 39 1216-32

Adhya TK and Pathak H (2013) Soil science in the changing climate and environmental scenario: Challenges and opportunities. Paper presented at the Indian Society of Soil Science Platinum Jubilee Symposium Proceedings

Alagawadi AR, Ammanna S and Doddagoudar CK (2014) Isolation and molecular characterization of endorhizospheric diazotrophs of Western Ghats $J$ Pure Appl Microbiol 8 3273-3278

Alagawadi AR, Ammanna S, Doddagouda CK, Marihal A and Krishnaraj PU (2014) Native isolates of Beijerinckia from Western Ghats producing high amount of indole acetic acid J Pure Appl Microbiol 8 4221-4224

Ali SZ, Sandhya V, Grover M, Linga VR and Bandi V (2011) Effect of inoculation with a thermotolerant plant growth promoting Pseudomonas putida strain AKMP7 on growth novel microbial species, hundreds of publications in highly rated journals and microbial technologies adopted in the field by farmers. All these are a cause for optimism. However, some caution is required in microbial taxonomy overly relying on molecular approaches alone. A combination of the classical and modern methods will be required to forge solutions for the above challenges which would ultimately contribute to more sustainable agricultural systems.

of wheat (Triticum spp.) under heat stress. J Plant Interact $6239-246$

Ambili K, Thomas GV, Indu P, Gopal M and Gupta A (2012) Distribution of arbuscular mycorrhizae associated with coconut and arecanut based cropping systems Agric Res $\mathbf{1}$ $338-345$

Anand S, Bala K, Saxena A, Schumann P and Lal R (2012) Microbacterium amylolyticum sp. nov., isolated from soil from an industrial waste site Int J Syst Evol Microbiol 62 2114-2120

Anima B and Singh K (2011) Genetic diversity analysis of Azotobacter strains native to Indian agricultural lands using RFLP technique Int J Medicobiol Res $1245-249$

Anjanadevi I P, John N S, John K S, Jeeva M L and Misra R S (2013) Isolation and characterization of $\mathrm{N}$ fixing bacteria from elephant foot yam (Amorphophallus paeniifolius (Dennst.) Nicolson) growing regions of South India J Root Crops 39 154-162

Anjanadevi IP, John NS, John KS, Jeeva ML and Misra RS (2016) Rock inhabiting potassium solubilizing bacteria from Kerala, India: characterization and possibility in chemical K fertilizer substitution J Basic Microbiol 56 67-77

Ansari PG and Rao DLN (2013) Differentiating indigenous soybean Bradyrhizobium and Rhizobium spp of Indian soils Indian J Microbiol 54 190-195

Ansari PG, Rao DLN and Pal KK (2014) Diversity and phylogeny of soybean rhizobia in central India Ann Microbiol 64 1553-1565

Ansari PG and Rao DLN (2014) Soybean Rhizobia in Indian Soils: Populations, Host Specificity and Competitiveness Proc Natl Acad Sci India, Section B Biological Sciences 84 457-464

Aparna K, Rao DLN and Balachandar D (2016) Microbial populations, activity and gene abundance in tropical Vertisols under intensive chemical farming Pedosphere 26 
$725-732$

Aparna K, Rao DLN and Manna MC (2014) Microbial inoculation of chickpea (Cicer arietinum L.) enhances rhizosphere effects on soil biological quality Agrochimica 58 114-125

Assam Agricultural University (2014) Exploitation of soil microfauna for sustainable cropping. In: Rao DLN (2014) Soil Biodiversity-Biofertilizers Research Progress 20122014, Bhopal, p 51-52

Assam Agricultural University (2016) Exploitation of soil microfauna for sustainable cropping. In: Rao DLN (2016) Soil Biodiversity-Biofertilizers Research Progress 20122014, AINP on Soil Biodiversity-Biofertilizers, ICARIndian Institute of Soil Science, Bhopal, p48-49

Asokan R, Swamy HMM, Thimmegowda GG and Mahmood R (2013) Diversity analysis and characterization of Coleoptera, Hemiptera and nematode-active cry genes in native isolates of Bacillus thuringiensis Ann Microbiol 64 85-98

Asokan R, Swamy HMM and Arora DK (2011) Screening, diversity and partial sequence comparison of vegetative insecticidal protein (vip3A) genes in the local isolates of Bacillus thuringiensis Berliner Curr Microbiol 64 365-70

Asokan R, Swamy HM, Birah A and Thimmegowda GG (2013) Bacillus thuringiensis isolates from Great Nicobar Islands Curr Microbiol 66 621-626

Atri NS, Kumari B and Upadhyay RC (2013) Chlorolepiota brunneotincta new species (Agaracaceae) from India Turkish J Bot 38 1-4

Babu BK, Reddy SS, Yadav MK, SuKumar M, Mishra V, Saxena AK and Arora DK (2010) Genetic diversity of Macrophomina phaseolina isolates from certain agroclimatic regions of India by using RAPD markers Indian J Microbiol 50 199-204

Bajaj A, Mayilraj S, Mudian MR, Patel DK and Manickam N (2014a) Isolation and functional analysis of a glycolipid producing Rhodococcus sp. strain IITR03 with potential for degradation of 1,1,1-trichloro-2,2-bis(4-chlorophenyl) ethane (DDT) Bioresource Technol 167 398-406

Bajaj A, Mayilraj S, Mudian MR, Patel DK and Manickam N (2014b) Isolation and characterization of a Pseudomonas sp. strain IITR01 capable of degrading á-endosulhan and endosulphan sulphate J Appl Microbiol 109 2135- 2143

Bal HB, Das S, Dangar TK and Adhya TK (2012) ACC deaminase and IAA producing growth promoting bacteria from the rhizosphere soil of tropical rice plants J Basic Microbiol 53 972-984

Bala K, Sharma P and Lal R (2010) Sphingobium quisquiliarum sp. nov., a hexachlorocyclohexane ( $\mathrm{HCH})$-degrading bacterium isolated from an $\mathrm{HCH}$-contaminated soil Int $J$ Syst Evol Microbiol 60 429-433

Balachandar D, Raja P, Nirmala K, Rithyl T and Sundaram S (2008) Impact of transgenic Bt-cotton on the diversity of pink-pigmented facultative methylotrophs World $J$ Microbiol Biotechnol 24 2087-2095

Bansal M, Kukreja K and Dudeja SS (2012) Diversity of Arbuscular mycorrhizal fungi, prevalent in rhizosphere of different crops grown in the university farm African $J$ Microbiol Res 6 4557-4566

Bhardwaj P, Sharma A, Sagarkar S and Kapley A (2015) Mapping atrazine and phenol degradation genes in Pseudomonas sp. EGD-AKN5 Biochem Eng J http://dx.doi.org/10.1016/ j.bej.2015.02.029

Bhatnagar A and Bhatnagar M (2005) Microbial diversity in desert ecosystems Curr Sci 89 91-100

Bhattacharjee K, Banerjee S, Bawitlung L, Krishnappa D and Joshi SR (2014) A Study on parameters optimization for degradation of endosulfan by bacterial consortia isolated from contaminated soil Proc Natl Acad Sci India Section B: Biological Sciences 84 657-667

Bhattacharjee RB, Jourand P, Chaintreuil C, Dreyfus B, Singh A and Mukhopadhyay SN (2012) Indole acetic acid and ACC deaminase-producing Rhizobium leguminosarum bv. trifolii SN10 promote rice growth, and in the process undergo colonization and chemotaxis Biol Fertil Soils 48 173-182

Bhattacharyya P, Roy KS, Das M, Ray S, Balachandar R, Karthikeyan S, Nayak AK and Mohapatra T (2016) Elucidation of rice rhizosphere metagenome in relation to methane and nitrogen metabolism under elevated carbon dioxide and temperature using whole genome metagenomic approach Sci Total Environ 542 886-898

Chakraborty BN, Chakraborty U, Dey PL and Sunar K (2010) Phylogenetic relationship of Trichoderma isolates of North Bengal based on sequence analysis of ITS region of rDNA J Appl Sci Res 6 1477-1482

Chakraborty BN, Chakraborty U, Saha A, Dey PL and Sunar K (2010) Molecular characterization of Trichoderma viride and Trichoderma harzianum isolated from soils of North Bengal based on rDNA markers and analysis of their PCR RAPD profiles Global J Biochem Biotechnol 5 55-61

Chakraborty BN, Dey PL, Shankar R, Adhikari J and Lama D (2010) Genetic relatedness between some saprophytic and parasitic macrofungi of Darjeeling Hills NBU J Plant Sic 4 $77-80$

Chaudhary D, Narula N, Sindhu SS and Behl RK (2013) Plant growth stimulation of wheat (Triticum aestivum L.) by 
inoculation of salinity tolerant Azotobacter strains Physiol Mol Biol Plants 19 515-519

Chauhan H, Bagyaraj DJ and Sharma A (2013) Plant growthpromoting bacterial endophytes from sugarcane and their potential in promoting growth of the host under field conditions Exp Agric 49 43-52

Chinnadurai C, Balachandar D and Sundaram S (2009) Characterization of 1-aminocyclopropane-1-carboxylate deaminase producing methylobacteria from phyllosphere of rice and their role in ethylene regulation World JMicrobiol Biotechnol 25 1403-1411

Chinnadurai C, Gopalaswamy G and Balachandar D (2014) Impact of long-term organic and inorganic nutrient managements on the biological properties and eubacterial community diversity of the Indian semi-arid Alfisol Arch Agron Soil Sci 60 531-548

Cinnadurai C, Gopalaswamy G and Balachandar D (2013) Diversity of cultivable Azotobacter in the semi-arid Alfisol receiving long-term organic and inorganic nutrient amendments Ann Microbiol 63 1397-1404

Choudhary KK and Bimal R (2010) Distribution of nitrogenfixing cyanobacteria (Nostocaceae) during rice cultivation in fertilized and unfertilized paddy fields Nordic J Bot $\mathbf{2 8}$ $100-103$

Dadhwal M, Jit S, Kumari H and Lal R (2009) Sphingobium chinhatense sp. nov., a hexachlorocyclohexane (HCH)degrading bacterium isolated from an $\mathrm{HCH}$ dumpsite Int $J$ Syst Evol Microbiol 59 3140-3144

Dangar TK, Babu YK and Das J (2010) Population dynamics of soil microbes and diversity of Bacillus thuringiensis in agricultural and botanic garden soils of India Afr J Biotechnol $9496-501$

Das J, Dangar TK and Adhya TK (2012) Microbial dynamics and diversity of Bacillus thuringiensis in textile effluent polluted and non-polluted rice field soils of Orissa, India Indian J Microbiol 53 18-27

Das K, Rajawat MVS, Saxena AK and Prasanna R (2017) Development of Mesorhizobium ciceri-based biofilms and analyses of their antifungal and plant growth promotinga in chickpea challenged by Fusarium wilt Indian $J$ Microbiol 57 48-59

Das S and Adhya TK (2012) Dynamics of methanogenesis and methanotrophy in tropical paddy soils as inûuenced by elevated $\mathrm{CO}_{2}$ and temperature interaction Soil Biol Biochem $4126-45$

Deepa SD, Oinam G, Devi I, Oinam T, Singh A, Tiwari ON and Sharma GD (2010) Ecology and biodiversity of cyanobacteria Assam Univ J Sci Technol Biol Enviro Sci 5
6-13

Dey PL, Chakraborty BN and Saha A (2013) Search for agriculturally important microorganisms from Terai-Dooars regions of North Bengal, analysis of their diversity and application for plant growth promotion and disease management J Mycol Plant Pathol 43 51-62

Dinesh R, Anandaraj M, Kumar A, Bini YK, Subila KP and Aravind R (2015) Isolation, characterization, and evaluation of multi-trait plant growth promoting rhizobacteria for their growth promoting and disease suppressing effects on ginger Microbiol Res 173 34-43

Dubey H, Rao DLN, Akhter S, Mehta G and Shahi DK (2016) Isolation of novel acid soil-tolerant isolates of Rhizobium from "Pigeon Pea" and proteomic characterization by utilizing MALDI-TOF/TOF and "Peptide Mass Fingerprinting" approach to identify genes associated with acid-soil tolerance Biotechnol Bioinform Bioengg (Accepted)

Dubey KK and Fulekar MH (2012) Chlorpyrifos bioremediation in Pennisetum rhizosphere by a novel potential degrader Stenotrophomonas maltophilia MHF ENV20 World J Microbiol Biotechnol 28 1715-1725

Dubey SK, Singh A, Singh RS and Upadhyay SN (2013) Changes in methanogenic population size and $\mathrm{CH}_{4}$ production potential in response to crop phenology in tropical rice field Soil Biol Biochem 57 972-978

Dubey SK, Singh A, Watanabe T, Asakawa S, Singla A, Hironori A and Inubushi K (2014) Methane production potential and methanogenic archaeal community structure in tropical irrigated Indian paddy soils Biol Fert Soil 50 369-379

Dudeja SS, Giri R, Saini R, Suneja Madan P and Kothe E (2012) Interaction of endophytic microbes with legumes J Basic Microbiol 52 248-260

Dukare AS, Prasanna R, Dubey SC, Nain L, Chaudhary V, Singh $R$ and Saxena AK (2011) Evaluating novel microbe amended composts as biocontrol agents in tomato Crop Prot 30 $436-442$

Dutta A, Vasudevan V, Lata Nain and Singh N (2016) Characterization of bacterial diversity in an atrazine degrading enrichment culture and degradation of atrazine, cyanuric acid and biuret in industrial wastewater $J$ Envion Sci Health Part B 51 24-34

Dutta S, Podile AR (2010) Plant growth promoting rhizobacteria (PGPR): The bugs to debug the root zone Crit Rev Microbiol 36 232-244

Dwivedi V, Kumari K, Gupta S K, Kumari R, Tripathi C, Lata P, Niharika N, Singh AK, Kumar R, Nigam A, Garg N and Lal $\mathrm{R}$ (2015) Thermus parvatiensis $\mathrm{RL}^{\mathrm{T}} \mathrm{sp}$. nov., isolated from 
a Hot Water Spring, Located Atop the Himalayan Ranges at Manikaran, India Indian J Microbiol 55 357-365

Dwivedi V, Niharika N and Lal R (2013) Pontibacter lucknowensis sp. nov., isolated from a hexachlorocyclohexane dump site Int J Syst Evol Microbiol 63 309-313

Garg N, Bala K and Lal R (2012) Sphingobium lucknowense sp. nov., a hexachlorocyclohexane ( $\mathrm{HCH})$-degrading bacterium isolated from $\mathrm{HCH}$-contaminated soil Int J Syst Evol Microbiol 62 618-623

Garg V, Kukreja K and Gera R (2016) Molecular diversity of berseem (Trifolium alexandrinum $\mathrm{L}$.) rhizobia isolated from Haryana soil Legume Res 39 729-733

Gauri SS, Mandal SM, Dey S and Pati BR (2012) Biotransformation of $p$-coumaric acid and 2, 4dichlorophenoxy acetic acid by Azotobacter sp. strain SSB81 Bioresource Technol 126 350-353

Gera R, Kumar V, Shekhawat K and Goyal S (2013) Genotypic diversity in native rhizobial population nodulating Vicia faba in arid and semi-arid regions of Haryana state (India) Ann Microbiol 64 619-626

Ghosh A, Dey N, Bera A, Tiwari A, Sathyaniranjan KB, Chakrabarti K and Chattopadhyay D (2010) Culture independent molecular analysis of bacterial communities in the mangrove sediment of Sundarban, India Saline systems 61

Ghosh PK, Das A, Saha R, Kharkrang E, Tripathi AK, Munda GC and Ngachan SV (2010) Conservation agriculture towards achieving food security in North East India Curr Sci 99 915-921

Ghosh S, Barinova S and Keshri JP (2012) Diversity and seasonal variation of phytoplankton community in the Santragachi Lake, West Bengal, India Qscience Connect 3

Giri K and Rai JPN (2012) Biodegradation of endosulfan isomers in broth culture and soil microcosm by Pseudomonas fluorescens isolated from soil Int J Environ Studies 69 729-742

Gopalakrishnan S, Srinivas V, Alekhya G and Prakash B (2015) Effect of plant growth-promoting Streptomyces sp. on growth promotion and grain yield in chickpea (Cicer arietinum L.) 3 Biotech 5 799-806

Gosal SK, Kalia A, Uppal SK, Kumar R, Walia SS, Singh K and Singh H (2012a) Assessing the benefits of Azotobacter bacterization in sugarcane: A field appraisal Sugar Tech $\mathbf{1 4}$ 61-67

Gosal SK, Saroa GS, Vikal Y, Cameotra SS, Pathania N and Bhanot A (2012b) Isolation and molecular characterisation of diazotrophic growth-promoting bacteria from wheat rhizospheric soils of Punjab Soil Res 49 725-732

Gupta P, Sangwan N, Lal R and Vakhlu J (2015) Bacterial diversity of Drass, cold desert in Western Himalaya, and its comparison with Antarctic and Arctic Arch Microbiol $197851-860$

Gupta S K, Kumari R, Prakash O and Lal R (2008) Pseudomonas panipatensis sp. nov., isolated from an oil-contaminated site Int J Syst Evol Microbiol 58 1339-1345

Gupta SK, Lal D and Lal R (2009) Novosphingobium panipatense sp. nov. and Novosphingobium mathurense sp. nov., from oil-contaminated soil Int J Syst Evol Microbiol 59 156-161

Indi DV and Alagawadi AR (2012) Diversity of fluorescent pseudomonads from Western Ghats of Uttara Kannada district of Karnataka for in vitro phosphate solubilization J Agric Res Tech 37 077-082

Jain R, Garg V and Yadav D (2014) In vitro comparative analysis of monocrotophos degrading potential of Aspergillus flavus, Fusarium pallidoroseum and Macrophomina sp. Biodegradation 25 437-446

Jesitha K, Nimisha KM, Manjusha CM and Harikumar PS (2015) Biodegradation of Endosulfan by Pseudomonas fluorescens. Environ Process 2 225-240

Jha M, Chourasia S and Sinha S (2013) Microbial consortium for sustainable rice production Agroecol Sust Food 37 340362

Jindal S, Dua A and Lal R (2013) Sphingopyxis indica sp. nov., isolated from a high dose point hexachlorocyclohexane (HCH)-contaminated dumpsite Int J Syst Evol Microbiol 63 2186-2191

Joshi PK, Swarup A, Maheshwari S, Kumar R and Singh N (2011) Bioremediation of heavy metals in liquid media through fungi isolated from contaminated sources Indian J Microbiol 51 482-487

Kaur J, Kaur J, Niharika N and Lal R (2012) Sphingomonas laterariae sp. nov., isolated from a hexachlorocyclohexanecontaminated dump site Int J Syst Evol Microbiol 62 28912896

Kaur J, Moskalikova H, Niharika N, Sedlackova M, Hampl A, Damborsky J, Prokop Z and Lal R (2013) Sphingobium baderi sp. nov., isolated from a hexachlorocyclohexane dump site Int J Syst Evol Microbiol 63 673-678

Kayasth M, Gera R and Kumar V (2014) Diversity of free living diazotrophs in salt affected areas of Haryana Ann Biol 30 227-234

Keswani C, Mishra S, Sarma BK, Singh SP and Singh HB (2014) Unraveling the efficient applications of secondary metabolites of various Trichoderma spp. Appl Microbiol 


\section{Biotechnol 98 533-544}

Keshari N and Adhikary SP (2013) Characterization of cyanobacteria isolated from biofilms on stone monuments at Santiniketan, India Biofouling 29 525-536

Kolekar PD, Phugare SS and Jadhav JP (2014) Biodegradation of atrazine by Rhodococcus sp. $\mathrm{BCH} 2$ to $\mathrm{N}$-isopropylammelide with subsequent assessment of toxicity of biodegraded metabolites Environ Sci Pollut Res 21 2334-2345

Kollah B, Dubey G, Saha JK and Mohanty SR (2014) Composting: An opportunity in a carbon conscious world for combating climate change Sci Res Essays 9 598-606

Kollah, B, Dubey G, Parasai P, Saha JK, Gangil S and Mohanty SR (2015) Interactive effect of biochar size and organic amendments on methane consumption in a tropical Vertisol Soil Use Manage 31 52-59

Kumar D, Kaštánek P and Adhikary SP (2016) Diversity of cyanobacteria in biological crusts on arid soils in the Eastern region of India and their molecular phylogeny Curr Sci 110 1999-2005

Kumar D, Kumar A and Sharma J (2016) Degradation study of lindane by novel strains Kocuria sp. DAB-1Y and Staphylococcus sp. DAB-1W. Bioresources Bioprocessing 353

Kumar M, Prasanna R, Bidyarani N, Babu S, Mishra BK, Kumar A, Adak A, Jauhari S, Yadav K, Singh R and Saxena AK (2013a) Evaluating the plant growth promoting ability of thermotolerant bacteria and cyanobacteria and their interactions with seed spice crops Sci Hort 164 94-101

Kumar M, Verma M and Lal R (2008) Devosia chinhatensis sp. nov., isolated from a hexachlorocyclohexane $(\mathrm{HCH})$ dump site in India Int J Syst Evol Microbiol 58 861-865

Kumar M, Yadav AN, Tiwari R, Prasanna R and Saxena AK (2013b) Deciphering the diversity of culturable thermotolerant bacteria from Manikaran hot springs. Ann Microbiol 64 741-751

Kumar M, Yadav AN, Tiwari R, Prasanna R and Saxena AK (2014) Evaluating the diversity of culturable bacteria from four hot springs of India J Biodivers Biopros Dev 1127 135

Kumar R, Bhowmick A, Chakdar H, Elumalai S and Pabbi S (2015) Biochemical characterization and diversity analysis of cyanobacteria isolated from Different Locations Vegetos 28 38-48

Kumar V, Rawat AK and Rao DLN (2017) Population Ecology of Soybean-Rhizobia in Diverse Crop Rotations in Central India Agric Ecosyst Environ 240 261-268

Kumar V, Singh P, Jorquera MA, Sangwan P, Kumar P, Verma AK and Agrawal S (2013) Isolation of phytase-producing bacteria from himalayan soils and their effect on growth and phosphorus uptake of Indian mustard (Brassica juncea) World J Microbiol Biotechnol 29 1361-1369

Kumari B, Atri NS and Kaur M (2013) Chlorolepiota indica sp. nov.-A new species from India Mycoscience 54 257-259

Kumari H, Gupta SK, Jindal S, Katoch P and Lal R (2009) Sphingobium lactosutens sp. nov., isolated from a hexachlorocyclohexane dump site and Sphingobium abikonense sp. nov., isolated from oil-contaminated soil Int J Syst Evol Microbiol 59 2291-2296

Kumari K, Sharma P, Tyagi K and Lal R (2011) Pseudoxanthomonas indica sp. nov., isolated from a hexachlorocyclohexane dumpsite Int J Syst Evol Microbiol $612107-2111$

Lakshmi CV, Kumar M and Khanna S (2009) Biodegradation of chlorpyrifos in soil by enriched cultures Curr Microbiol $5835-8$

Lal D, Gupta SK, Schumann P and Lal R (2010) Microbacterium lindanitolerans sp. nov., isolated from hexachlorocyclohexane-contaminated soil Int J Syst Evol Microbiol 60 2634-2638

Makandar MB and Bhatnagar A (2010a) Biodiversity of Microalgae and Cyanobacteria from freshwater bodies of Jodhpur, Rajasthan (India) J Algal Biomass Utln 1 54-69

Makandar MB and Bhatnagar A (2010b) Morphotypic diversity of microalgae from arid zones of Rajasthan (India) $\mathrm{J} \mathrm{Algal}$ Biomass Utln 1 74-9

Malhotra J, Anand S, Jindal S, Rajagopal R and Lal R (2012) Acinetobacter indicus sp. nov., isolated from a hexachlorocyclohexane dump site Int J Syst Evol Microbiol 62 2883-2890

Malhotra J, Aparna K, Dua A, Sangwan N, Trimurtulu N, Rao D and Lal R (2015) Microbial and genetic ecology of tropical Vertisols under intensive chemical farming Environ Monitor Assess 187 1-17

Manna M, Sahu A, Singh A, Subba Rao A and Khanna SS (2014) Quality compost production from solid urban waste Scientific Bulletin no.2/IISS/2014, IISS, Bhopal, pp 52

Maske SS, Sangolkar LN and Chakrabarti T (2010) Temporal variation in density and diversity of cyanobacteria and cyanotoxins in lakes at Nagpur (Maharashtra State) India Environ Monit Assess 169 299-308

Maya K, Singh RS, Upadhyay SN and Dubey SK (2011) Kinetic analysis reveals bacterial efficacy for biodegradation of chlorpyrifos and its hydrolyzing metabolite TCP Process Biochem 46 2130-2136

Maya K, Upadhyay SN, Singh RS and Dubey SK (2012) 
Degradation kinetics of chlorpyrifos and 3,5,6-trichloro2-pyridinol (TCP) by fungal communities Bioresource Technol 126 216-223

Meena KK, Kumar M, Kalyuzhnaya HG, Yandigeri MS, Singh DP, Saxena AK and Arora DK (2011) Epiphytic pink pigmented methylotrophic bacteria enhances germination and seedling growth of wheat (Triticum aestivum) by producing phytohormones Antonie van Leeuwenhoek 101 $777-86$

Meena KK, Mespogu S, Kumar M, Yandigeri M, Singh G and Saxena AK (2010) Co-inoculation of endophytic fungus Piriformaspora indica with the phosphate solubilizing bacterium Pseudomonas striata affects population dynamics and plant growth in chickpea Biol Fertil Soils $\mathbf{4 6}$ 169-174

Mesapogu S, Bakshi A, Babu BK, Reddy SS, Saxena S and Arora DK (2012) Genetic diversity and pathogenic variability among Indian isolates of Fusarium udum infecting pigeonpea [Cajanus cajan (L.) millsp.] Int Res J Agric Sci Soil Sci 2 51-57

Mishra PK, Bisht SC, Ruwari P, Selvakumar G, Joshi GK, Bisht JK, Bhatt JC and Gupta HS (2011) Alleviation of cold stress in inoculated wheat (Triticum aestivum $\mathrm{L}$.) seedlings with psychrotolerant Pseudomonads from NW Himalayas Arch Microbiol 193 497-513

Mohanty S, Kollah B, Chaudhary RS, Singh AB and Singh M (2015) Methane uptake in tropical soybean-wheat agroecosystem under different fertilizer regimes ýEnviron Earth Sci 74 5049-5061

Mohanty SR, Tiwari S, Dubey G, Ahirwar U and Kollah B (2016) How methane feedback response influence redox processes in a tropical Vertisol Biol Fertil Soils 52 479-490

Murthy KN, Malini M, Savitha J and Srinivas C (2013) Lactic acid bacteria (LAB) as plant growth promoting bacteria (PGPB) for the control of wilt of tomato caused by Ralstonia solanacearum. Pest Management In: Horticultural Ecosystems 18 60-65

Naampoothiri KM, Ramkumar B and Pandey A (2013) Western Ghats of India: Rich source of microbial biodiversity $J \mathrm{Sci}$ Ind Res 72 617-623

Nath D, Ozah B, Baruah R, Barooah R, Borah D and Gupta M (2012) Soil enzymes and microbial biomass carbon under rice-toria sequence as influenced by nutrient management J Indian Soc Soil Sci 60 20-24

Negi V, Singh Y, Schumann P and Rup Lal (2016) Corynebacterium pollutisoli sp. nov., isolated from hexachlorocyclohexane-contaminated soil Intl J Syst Evol Microbiol 66 3531-3537
Nigam A, Jit S and Lal R (2010) Sphingomonas histidinilytica sp. nov., isolated from a hexachlorocyclohexane dump site Int J Syst Evol Microbiol 60 1038-1043

Pailan S, Gupta D, Apte S, Krishnamurthi S and Saha P (2015) Degradation of organophosphate insecticide by a novel Bacillus aryabhattai strain SanPS1, isolated from soil of agricultural field in Burdwan, West Bengal, India Intl Biodeter Biodegrad 103 191-195

Pandit AS, Joshi MN, Bhargava P, Shaikh I, Ayachit GN, Raj SR, Saxena AK and Bagatharia SB (2015) A snapshot of microbial communities from the Kutch: one of the largest salt deserts in the World Extremophiles 19 973-987

Panneerselvam P, Saritha B, Mohandas S, Upreti KK, Poovarasan S, Sulladmath VV and Venugopalan R (2013) Effect of mycorrhiza-associated bacteria on enhancing colonization and sporulation of Glomus mosseae and growth promotion in sapota (Manilkara achras (Mill) Forsberg) seedlings Biol Agric Hortic 29 118-131

Pradhan S, Srinivas TNR, Pindi PK, Kishore KH, Begum Z, Singh PK and Shivaji S (2010) Bacterial biodiversity from Roopkund glacier, Himalayan mountain ranges, India Extremophiles 14 377-395

Prasanna R, Arun Kumar, Santosh Babu, Gautam Chawla, Vidhi Chaudhary, Surender Singh, Vishal Gupta, Lata Nain and Saxena AK (2013) Deciphering the biochemical spectrum of novel cyanobacterium based biofilms for use as inoculants Biol Agric Hort 29 145-158

Prasanna R, Patnayak S, Sugitha TCK, Nain L and Saxena AK (2010) Development of cyanobacterium based biofilms and their in vitro evaluation for agriculturally useful traits Folia Microbiol 56 49-58

Prasanna R, Triven S, Bidyarani N, Babu S, Yadav K, Adak A, Khetarpal S, Pal M, Shivay YS and Saxena AK (2014) Evaluating the efficacy of cyanobacterial formulations and biofilmed inoculants for leguminous crops Arch Agron Soil Sci 60 349-366

Praveen Kumar G, Desai S, Leo Daniel Amalraj E, Mir Hassan Ahmed SK and Reddy G (2012) Plant Growth Promoting Pseudomonas spp. from Diverse Agro-Ecosystems of India for Sorghum bicolor L. J Biofert Biopest S7: 001

Priya H, Prasanna R, Ramakrishnan B, Bidyarani N, Babu S, Thapa S and Renuka N (2015) Influence of cyanobacterial inoculation on the culturable microbiome and growth of rice Microbiol Res 171 78-89

Radha TK and Rao DLN (2014) Plant Growth Promoting Bacteria from Cow Dung based Biodynamic Preparations Indian J Microbiol 54 413-418 
Raghuraman M, Yadav RS and Singh J (2010) Biodiversity of Collembola at Varanasi Ind J Entomol 72 333-336

Rahul Sri Balaji, Dhamodharan G and Rajasekar A (2013) Isolation and characterization of methylotrophic bacteria from Western Ghats Int J Eng Res Technol 2 1752-1756

Rai R, Dash P, Mohapatra T and Singh A (2012) Phenotypic and molecular characterization of indigenous rhizobia nodulating chickpea in India Indian J Exp Biol $50340-350$

Rajeela TK, Gopal M, Gupta A, Bhat R and Thomas GV (2017) Cross-compatibility evaluation of plant growth promoting rhizobacteria of coconut and cocoa on yield and rhizosphere properties of vegetable crops Biocatal Agric Biotechnol 9 $67-73$

Rajkumar M, Prasad MNV, Swaminathan S and Freitas H (2013) Climate change driven plant-metal-microbe interactions Environ Intl 53 74-86

Ramadoss D, Lakkineni VK, Bose P, Ali S and Annapurna K (2013) Mitigation of salt stress in wheat seedlings by halotolerant bacteria isolated from saline habitats Springer Plus 2 1-7

Ramalakshmi A and Udayasuriyan V (2010) Diversity of Bacillus thuringiensis isolated from Western Ghats of Tamil Nadu State, India Curr Microbiol 61 13-18

Ramesh A, Sharma SK, Sharma MP, Yadava N and Joshi OP (2014) Inoculation of zinc solubilizing Bacillus aryabhattai strains for improved growth, mobilization and biofortification of zinc in soybeanand wheat cultivated in Vertisols of central India Appl Soil Ecol 73 87-96

Rana A, Joshi M, Prasanna R, Shivay YS and Nain L (2012) Biofortification of wheat through inoculation of plant growth promoting rhizobacteria and cyanobacteria Eur $J$ Soil Biol 50 118-126

Rao DLN (2013) Soil biological health and its management Soil health management: productivity-sustainability-resource management FDCO, New Delhi: 55-83

Rao DLN (2014a) Recent advances in biological nitrogen fixation in agricultural systems Proc Indian Nat Sci Acad 80359 378

Rao DLN (2014b) Soil Biodiversity-Biofertilizers Research Progress 2012-2014, Bhopal, p 22-24

Rao DLN (2016) Soil Biodiversity-Biofertilizers Research Progress 2012-2014, AINP on Soil BiodiversityBiofertilizers, ICAR-Indian Institute of Soil Science, Bhopal, pp 90

Rao DLN, Aparna K, Krishnaraj PU, Balachandar D and Lal R (2014) Soil biological health: Unified indicators across soil types and management practices. Paper presented at the 55th Annual conference of Association of Microbiologists of India, Tamil Nadu Agricultural University, Coimbatore, India, 1-4

Rao DLN and Balachandar D (2017) Nitrogen inputs from Biological Nitrogen Fixation in Indian Agriculture. In: The Indian Nitrogen Assessment. Sources of Reactive Nitrogen, Environmental and Climate Effects, Management Options, and Policies. YP Abrol et al. (ed), pp 117-132, Elsevier

Rao DLN, Balachandar D and Thakuria D (2015) Soil Biotechnology and Sustainable Agricultural Intensification Indian Journal of Fertilisers 11 87-105

Rastogi RP, Kumari S, Han T and Sinha RP (2012) Molecular characterization of hot spring cyanobacteria and evaluation of their photoprotective compounds Can J Microbiol 58 719-727

Rawat AK, Khatik SK, Rao DLN and Saxena AK (2008) Soybean rhizobial inoculants survey in Madhya Pradesh. All India Network Project on Biofertilizers Bulletin. Jawahar Lal Nehru Krishi Vishwa Vidyalaya, Jabalpur, pp. 32

Rawat AK, Rao DLN and Sahu RK (2013) Effect of soybean inoculation with Bradyrhizobium and wheat inoculation with Azotobacter on their productivity and $\mathrm{N}$ turnover in a Vertisol Arch Agron Soil Sci 59 1559-1571

Sagarkar S, Mukherjee S, Nousiainen A, Björklöf K Purohit HJ, Jørgensen KS and Kapley A (2013) Monitoring bioremediation of atrazine in soil microcosms using molecular tools Environ Pollu 172 108-115

Sahai R, Saxena AK and Tilak KVBR (2015) Effect of Gluconacetobacter diazotrophicus on sweet sorghum (Sorghum bicolor (L.) Moench in tropical semi-arid soil Agri Res 4 347-353

Sahay H, Babu K, Kaushik R, Saxena AK and Arora DK (2012b) Cold-active hydrolases producing bacteria from two different sub-glacial Himalayan lakes J Basic Microbiol 52 $1-13$

Sahay H, Mahfooz S, Singh AK, Singh S, Kaushik R, Saxena AK and Arora DK (2012a) Exploration and characterization of agriculturally and industrially important haloalkaliphilic bacteria from environmental samples of hypersaline Sambhar lake, India World J Microbiol Biotechnol 283207 3217

Sahay H, Singh S, Kaushik R, Saxena AK and Arora DK (2011) Characterization of halophilic bacteria from environmental samples of Pulicat brackish water lake Biologia 66 741747

Saini R, Dudeja SS, Giri R and Kumar V (2015) Isolation, characterization, and evaluation of bacterial root and nodule endophytes from chickpea cultivated in Northern India $J$ 
Basic Microbiol 55 74-81

Sandhya V, Ali SZ, Grover M, Reddy G and Venkateswarlu B (2010) Effect of plant growth promoting Pseudomonas spp. on compatible solutes, antioxidant status and plant growth of maize under drought stress J Plant Growth Regul 62 21-30

Saravanakumar D, Kavino M, Raguchander T, Subbian P and Samiyappan R (2011) Plant growth promoting bacteria enhance water stress resistance in green gram plants Acta Physiol Plant 33 203-209

Sarkar B, Patra A and Purakayastha T (2008) Transgenic Bt Cotton affects enzyme activity and nutrient availability in a Sub tropical Inceptisol J Agron Crop Sci 194 289-296

Sarkar B, Patra AK, Purakayastha T and Megharaj M (2009) Assessment of biological and biochemical indicators in soil under transgenic Bt and non-Bt cotton crop in a subtropical environment Environ Monitor Assess 156 595604

Sasikala C, Jiwal S, Rout P and Ramya M (2012) Biodegradation of chlorpyrifos by bacterial consortium isolated from agriculture soil World J Microbiol Biotechnol 28 13011308

Saxena AK (2006) Changing face of soybean- Rhizobium symbiosis in the state of Madhya Pradesh. Presented at 47th AMI Conference held at Barkatullah University, Bhopal, 6-8 December, 2006

Sharma A, Jani K, Shouche YS and Pandey A (2015) Microbial diversity of the Soldhar hot spring, India, assessed by analyzing 16S rRNA and protein-coding genes Ann Microbiol 65 1323-1332

Sharma A, Kohli P, Singh Y, Schumann P and Lal R (2016) Fictibacillus halophilus sp. nov., isolated from a microbial mat of a hot spring situated atop the Himalayan Ranges at Manikaran Int J Sys Evo Microbiol 66 2409-2416

Sharma A, Singh P, Kumar S, Kashyap PL Srivastava AK, Chakdar H, Singh RN, Kaushik R, Saxena AK and Sharma AK (2015) Deciphering Diversity of Salt-Tolerant Bacilli from Saline Soils of Eastern Indo-gangetic Plains of India Geomicrobiol J 32 170-180

Sharma P, Singh G and Singh RP (2011) Conservation tillage, optimal water and organic nutrient supply enhance soil microbial activities during wheat (Triticum aestivum $\mathrm{L}$.) cultivation Braz J Microbiol 42 531-542

Sharma P, Verma M, Bala K, Nigam A and Lal R (2010) Sphingopyxis ummariensis sp. nov., isolated from a hexachlorocyclohexane dump site Int J Sys Evo Microbiol $60780-784$

Sharma SK, Sharma PK, Kumar R, Yadav RC, Malviya D and
Vaishnav A (2015) Significant achievements, Application of Microorganisms in Agriculture and Allied Sectors (20062014) published by ICAR- National Bureau of Agriculturally Important Microorganisms, Kushmaur, Mau Nath Bhanjan 275103, Uttar Pradesh, India, 199pp.

Shivaji S, Pratibha MS, Sailaja B, Kishore KH, Singh AK, Begum Z and Srinivas TN R (2011) Bacterial diversity of soil in the vicinity of Pindari glacier, Himalayan mountain ranges, India, using culturable bacteria and soil 16S rRNA gene clones Extremophiles 15 1-22

Shukla A, Dhauni N, Suyal DC, Kumar S and Goel R (2015) Comparative plant growth promoting potential of psychrotolerant diazotrophs, Pseudomonas sp. JJS2 and Enterobacter sp. AAB8 against native Cajanus cajan (L.) and Eleusine coracana (L.) African J Microbiol Res 91371 1375

Shukla L, Suman A, Verma P, Yadav AN and Saxena AK (2016) Syntrophic microbial system for ex-situ degradation of paddy straw at low temperature under controlled and natural environment $J$ App Biol Biotech 4 030-037

Silambarasan S and Abraham J (2013) Ecofriendly Method for Bioremediation of chlorpyrifos from agricultural soil by novel fungus Aspergillus terreus JAS1 Water Air Soil Pollut 2241369

Silambarasan S and Abraham J (2014) Efficacy of Ganoderma sp. JAS4 in bioremediation of chlorpyrifos and its hydrolyzing metabolite TCP from agricultural soil J Basic Microbiol 54 44-55

Singh A and Dubey SK (2012) Temporal variations in methanogenic community structure and methane production potential of tropical rice ecosystems Soil Biol Biochem 48 162-166

Singh AK, Garg N, Sangwan N, Negi V, Kumar R, Vikram S and Lal R (2013) Pontibacter ramchanderi sp. nov., isolated from hexachlorocyclohexane-contaminated pond sediment Int J Syst Evol Microbiol 63 2829-2834

Singh AK, Tripathi BM, Sahay H, Singh RN, Kaushik R, Saxena AK and Arora DK (2010) Biochemical and molecular characterization of thermo-alkali tolerant xylanase producing bacteria from thermal springs of Manikaran Indian J Microbiol $50 \mathrm{~S} 2-\mathrm{S} 9$

Singh A, Singh RS, Upadhyay SN, Joshi CG, Tripathi AK and Dubey SK (2012) Community structure of methanogenic archaea and methane production associated with composttreated tropical rice-field soil FEMS Microbiol Ecol $\mathbf{8 2}$ $118-134$

Singh A, Singh RV, Saxena AK, Shivay YS and Nain L (2014) Comparative studies on composting efficiency of Eisenia 
foetida (Savigny) and Perionyx excavatus (Perrier) Journal of Experimental Biology and Agricultural Sciences 2 508517

Singh B (2013) Degradation of Clodinafop Propargyl by Pseudomonas sp. Strain B2 Bull Environ Contam Toxicol 91 730-733

Singh D, Rajawat MVS, Kaushik R, Prasanna R and Saxena AK (2017) Beneficial role of endophytes in biofortification of $\mathrm{Zn}$ in wheat genotypes varying in nutrient use efficiency grown in soils sufficient and deficient in Zn Plant Soil doi:10.1007/s11104-017-3189-x)

Singh NS and Singh DK (2011) Biodegradation of endosulfan and endosulfan sulfate by Achromobacter xylosoxidans strain C8B in broth medium Biodegradation 22 845-857

Singh P, Raghukumar C, Verma P and Shouche Y (2010) Phylogenetic diversity of culturable fungi from the deepsea sediments of the Central Indian Basin and their growth characteristics Fungal Diversity 40 89-102

Singh RN, Kaushik R, Arora DK and Saxena AK (2013) Prevalence of opportunist pathogens in thermal springs of devotion $J$ Appl Sci Environ Sanit 8 195-203

Singh SK, Verma P, Ramaiah N, Chandrashekar AA and Shouche YS (2010) Phylogenetic diversity of archaeal 16S rRNA and ammonia monooxygenase genes from tropical estuarine sediments on the central west coast of India Res Microbiol 161 177-186

Singh Y, Khattar JIS, Singh DP, Rahi P and Gulati A (2014) Limnology and cyanobacterial diversity of high altitude lakes of Lahaul-Spiti in Himachal Pradesh, India J Biosci 39 643-657

Srinivas TNR, Singh SM, Pradhan S, Pratibha MS, Kishore KH, Singh AK and Shivaji S (2011) Comparison of bacterial diversity in proglacial soil from Kafni Glacier, Himalayan Mountain ranges, India, with the bacterial diversity of other glaciers in the world Extremophiles 15 673-690

Srinivasan R, Alagawadi AR, Yandigieri MS, Meena KK and Saxena AK (2011) Characterization of phosphate solubilizing microorganisms from salt affected soils of India and their effect on growth of sorghum plants [Sorghum bicolor (L) Moench] Ann Microbiol 62 93-105

Subhashini DV (2012) Bioherbicidal activity of Streptomyces spp. isolated from tobacco rhizosphere against certain dicot and monocot weeds Indian J Agr Sci 82

Subhashini DV (2014) Antifungal activity of Streptomyces spp. against different plant pathogenic fungi of tobacco Indian J Plant Prot 42 474-476

Suman A, Yadav AN and Verma P (2016) Endophytic microbes in crops: diversity and beneficial impact for sustainable agriculture In Microbial Inoculants in Sustainable Agricultural Productivity (pp. 117-143). Springer India

Suneja P, Piplani S, Dahiya P and Dudeja SS (2016) Molecular characterization of rhizobia from revertants of nonnodulating cultivar and normal cultivar of chickpea J Agric Sci Technol 18 763-773

Suyal DC, Yadav A, Shouche Y and Goel R (2015) Diversified diazotrophs associated with the rhizosphere of Western Indian Himalayan native red kidney beans (Phaseolus vulgaris L.). Biotech 5 433-441

Swarnalakshmi K, Prasanna R, Kumar A, Pattnaik S, Chakravarty K, Shivay YS Singh R and Saxena AK (2013) Evaluating the influence of novel cyanobacterial biofilmed biofertilizers on soil fertility and plant nutrition in wheat Eur J Soil Biol 55 105-116

Swer H, Dkhar MS and Kayang H (2011) Fungal population and diversity in organically amended agricultural soils of Meghalaya, India J Organic Systems 6 3-12

Tamilselvi S, Chinnadurai C, Ilamurugu K, Arulmozhiselvan K and Balachandar D (2015) Effect of long-term nutrient managements on biological and biochemical properties of semi-arid tropical Alfisol during maize crop development stages Ecol Indic 48 76-87

Thakuria D and Sharma UC (2014) National Academy of Agricultural Sciences News 14 4-8

Thakuria D, Talukdar NC, Goswami C, Hazarika S, Kalita MC and Bending GD (2009) Evaluation of rice-legume-rice cropping system on grain yield, nutrient uptake, nitrogen fixation, and chemical, physical, and biological properties of soil Biol Fertil Soils 45 237-251

Thomas M, Pal KK, Dey R, Saxena AK and Dave SR (2012) A novel haloarchaeal lineage widely distributed in the hypersaline marshy environment of little and Great Rann of Kutch in India Curr Sci 103 1078-1084

Tilak KVBR, Ranganayaki N, Pal KK, De R, Saxena AK, Nautiyal CS, Mittal S, Tripathi AK and Johri BN (2005) Diversity of plant growth and soil health supporting bacteria Curr Sci 89 136-150

Trimurtulu N and Rao DLN (2014) Liquid Microbial Inoculants and their Efficacy on Field crops. AINP on Soil Biodiversity and Biofertilizers Bulletin, ANGRAU, Agricultural Research Station, Amaravathi, pp 54

Tripathi BM, Kumari P, Weber KP, Saxena AK, Arora DK and Kaushik R (2013) Influence of long term irrigation with pulp and paper mill effluent on the bacterial community structure and catabolic function in soil Indian J Microbiol 54 65-73 
Tripathi C, Mahato NK, Singh AK, Karma K and Karpole LR (2016) Lampropedia cohaerens sp. nov., a biofilm-forming bacterium isolated from microbial mats of a hot water spring, and emended description of the genus Lampropedia Int J Sys Evol Microbiol 66 1156-1162

Triveni S, Bidyarani N, Yadav K, Prasanna R and Saxena AK (2012a) Development of formulations for Trichoderma based biofilms using different carriers Pusa Agriscience 35 66-72

Triveni S, Prasanna R and Saxena AK (2012b) Optimization of conditions for in vitro development of Trichoderma viridebased biofilms as potential inoculants Folia Microbiol 57 431-437

Triveni S, Prasanna R, Kumar A, Bidyarani N, Singh R and Saxena AK (2015) Evaluating the promise of Trichoderma and Anabaena based biofilms as multifunctional agents in Macrophomina phaseolina-infected cotton crop Biocontrol Sci Tech 25 656-670

Triveni S, Prasanna R, Shukla L and Saxena AK (2012c) Evaluating the biochemical traits of nov el Trichoderma-basedbiofilms for use as plant growth promoting inoculants $A n n$ Microbiol (doi:10.1007/s13213-012-0573-x)

Tsigie A, Tilak KV and Saxena AK (2011) Field response of legumes to inoculation with plant growth-promoting rhizobacteria Biol Fertil Soils 47971

Upadhyay RC, Kaur A, Kumari D, Semwal KC and Gulati A (2008) New records and taxonomy of Agaricales from North Western Himalaya J Mycol Plant Pathol 38158-163

Upadhyay SK, Singh JS, Saxena AK and Singh DP (2012) Impact of PGPR inoculation on growth and antioxidants status of wheat plant under saline condition Plant Biol 14 605-616

Verma M, Kumar M, Dadhwal M, Kaur J and Lal R (2009) Devosia albogilva sp. nov. and Devosia crocina sp. nov., isolated from a hexachlorocyclohexane dump site Int J Syst Evol Microbiol 59 795-799

Verma P, Yadav AN, Kazy SK, Saxena AK and Suman A (2014) Evaluating the diversity and phylogeny of plant growth promoting bacteria associated with wheat (Triticum aestivum) growing in central zone of India Int J Curr Microbiol Appl Sci 3 432-447

Verma P, Yadav AN, Khannam KS, Kumar S, Saxena AK and Suman A (2016a) Molecular diversity and multifarious plant growth promoting attributes of Bacilli associated with wheat (Triticum aestivum L.) rhizosphere from six diverse agro-ecological zones of India J Basic Microbiol 56 44-58

Verma P, Yadav AN, Khannam KS, Kumar S, Saxena AK and Suman A (2016b) Appraisal of diversity and functional attributes of thermotolerant wheat (Triticum aestivum L.) associated bacteria from the peninsular zone of India Saudi J Biol Sci doi: 10.1016/j.sjbs.2016.01.042

Verma P, Yadav AN, Khannam KS, Panjiar N, Kumar S, Saxena AK and Suman A (2015) Assessment of genetic diversity and plant growth promoting attributes of psychrotolerant bacteria allied with wheat (Triticum aestivum) from northern hills zone of India Ann Microbiol 65 1885-1899

Wadhwa K, Dudeja SS and Yadav RK (2011) Molecular diversity of native rhizobia trapped by five field pea genotypes in Indian soils J Basic Microbiol 51 89-97

Yadav AN, Sachan SG, Verma P, Kaushik R and Saxena AK (2016b) Cold active enzymes production by psychrotrophic Bacilli isolated from three sub-glacial lakes of NW Indian Himalayas J Basic Microbiol 56 294-307

Yadav AN, Sachan SG, Verma P and Saxena AK (2015b) Prospecting cold deserts of north western Himalayas for microbial diversity and plant growth promoting attributes J Biosci Bioeng 119 683-693

Yadav AN, Sachan SG, Verma P and Saxena AK (2016a) Bioprospecting of plant growth promoting psychrotrophic Bacilli from cold desert of north western Indian Himalayas Indian J Exp Biol 54 142-150

Yadav AN, Sachan SG, Verma P, Taygi SP, Kaushik R and Saxena AK (2015a) Culturable diversity and functional annotation of psychrotrophic bacteria from cold desert of Leh Ladakh (India) World J Microbiol Biotechnol 31 95-108

Yadav AN, Sharma D, Gulati S, Singh S, Dey R, Pal KK, Kaushik R and Saxena AK (2015d) Haloarchaea endowed with phosphorus solubilization attribute implicated in phosphorus cycle Sci Rep 512293 doi: 10.1038/srep12293

Yadav AN, Verma P, Kumar M, Pal KK, Dey R, Gupta A, Padaria JC, Gujar GT, Kumar S, Suman A, Prasanna R, Suman A and Saxena AK (2015c) Diversity and phylogenetic profiling of niche-specific Bacilli from extreme environments of India Ann Microbiol 65 611-629

Yadav A, Singh AL, Rai GK and Singh M (2013) Assessment of molecular diversity in chickpea (Cicer arietinum L.) rhizobia and structural analysis of $16 \mathrm{~S}$ rDNA sequences from Mesorhizobium ciceri. Polish J Microbiol 62 253262

Yadav S, Kaushik R, Saxena AK and Arora DK (2011) Diversity and Phylogeny of plant growth promoting Bacilli from moderately acidic soil J Basic Microbiol 51 98-106

YSPUHF (2014) Annual Report, AINP on Soil BiodiversityBiofertilizers, In: Rao DLN (2014) Soil BiodiversityBiofertilizers Research Progress 2012-2014, Bhopal, p 22-24. 